\title{
DRY GRASSLAND COMMUNITIES OF ERYSIMO-TRIFOLIETUM IN THE NORTH- EASTERN PART OF THE REPUBLIC OF MACEDONIA
}

\author{
Renata ĆUŠTEREVSKA ${ }^{1 *}$, Vlado MATEVSKI ${ }^{1,2}$, Mitko KOSTADINOVSKI $^{1}$ \\ \& Andraž ČARNI ${ }^{3,4}$
}

\begin{abstract}
The study deals with the distribution and classification of the association Erysimo-Trifolietum Micevski 1977 (alliance Trifolion cherleri Micevski 1971, order Astragalo-Potentilletalia Micevski 1971, class Festuco-Brometea Br. Bl. et Tx. 1943). The association develops on siliceous bedrock of the northern and northeastern parts of the Republic of Macedonia. After the research of dry grasslands in the region of Kratovo, enough information was available to prepare a synthetic overview of the association Erysimo-Trifolietum. Within the frame of this association, two new subassoaciations are described - subass. scleranthetosum subass. nova and subass. brachypodietosum subass. nova. Analysis of geoelements showed that sub-Mediterranean species are the most numerous and analysis of life forms provided evidence of their therophyto-hemicryptophytic physiognomy. The paper also presents the localities of occurrence, their floristic composition, synecological characteristics, life forms incidence and areal types. Key words: Erysimo-Trifolietum, geoelements, life forms, syntaxonomy, vegetation, Republic of Macedonia.
\end{abstract}

\section{Izvleček}

Raziskava se ukvarja z razširjenostjo in klasifikacijo asociacije Erysimo-Trifolietum Micevski 1977 (zveza Trifolion cherleri Micevski 1971, red Astragalo-Potentilletalia Micevski 1971, razred Festuco-Brometea Br. Bl. et Tx. 1943). Asociacija se pojavlja na silikatni podlagi v severnem in severovzhodnem delu Republike Makedonije. Po zaključenih raziskavah v okolici Kratova, smo razpolagali z zadostno količino podatkov, da smo lahko pripravili sintetični pregled asociacije Erysimo-Trifolietum. V okviru asociacije smo opisali dve novi subasociaciji - subasociacijo sclerathetosum subass. nova in brachypodietosum subass. nova. Analiza horološkega spektra je pokazala, da so $\mathrm{v}$ združbah najbolj pogoste submediteranske vrste, analiza življenjskih oblik pa kaže na terofitsko-hemikriptofitski značaj te asociacije. Delo prikazuje lokalitete, kjer se združbe pojavljajo, floristično zgradbo, sinekološke značilnosti, spekter življenjskih oblik in horološki spekter.

Ključne besede: Erysimo-Trifolietum, geoelementi, življenjske oblike, sintaksonomija vegetacija, Republika Makedonija.

\section{INTRODUCTION}

Dry grasslands have existed in the landscape of Europe since the Pleistocene and they are western outposts of the vast steppes of Russia and the Ukraine (Kuneš et al. 2008, Werger 2009), and can be primary and secondary. On the territory of the Republic of Macedonia they are maintained by human activities. With the abandonment of traditional agriculture, they have become overgrown, mainly by thermophilous deciduous forest of Quercetalia pubescentis. During the $20^{\text {th }}$ century, they therefore became fragmented and are among endangered habitats. Various activities

\footnotetext{
${ }^{1}$ Institute of Biology, Faculty of Natural Sciences and Mathematics, University of Ss. Cyril and Methodius, Gazi Baba b/b - P.O. Box 162, MK-1000 Skopje, Republic of Macedonia.

${ }^{2}$ Macedonian Academy of Sciences and Arts, Bul. Krste Misirkov, 2, P.O. Box 428, MK-1000 Skopje, Republic of Macedonia.

${ }^{3}$ Institute of Biology, Scientific Research Center of the Slovenian Academy of Sciences and Arts, Novi trg 2, SI-1000 Ljubljana, Slovenia.

${ }^{4}$ University of Nova Gorica, Vipavska cesta 13, SI-5000 Nova Gorica, Slovenia.

* corresponding author: renatapmf@yahoo.com
} 
for the preservation of dry grasslands are taking place throughout Europe. (Dzwonko \& Loster 2007, Kiehl \& Pfadenauer 2007, Dostalek \& Frantik 2008, Čarni \& al. 2009, Kavgaci \& al. 2010)

In continental parts of Europe, dry grasslands of lower altitudes are mainly classified within the class of Festuco-Brometea. In Atlantic and sub-Atlantic parts of Europe, appearing also in the western part of the Balkan Peninsula, there appear lowland dry grasslands over acidic substrate, dominated by Nardus stricta, but in the southern Balkans, such vegetation appears at higher altitudes and can be classified within $\mathrm{Cal}$ luno-Ulicetea or Funcetea trifidi. (Micevski 1994, Redžić 2007, Velev \& Apostolova 2009)

Dry grasslands in the southern part of the Balkan Peninsula are classified in the endemic order Astragalo-Potentilletalia within the class FestucoBrometea. (Micevski 1971, Rodwell et al. 2002, Bergmeier \& al. 2009).

The dry grasslands on siliceous geological bedrock on the territory of the Republic of Macedonia are assigned to the class Festuco-Brometea, order Astragalo-Potentilletalia and alliance Trifolion cherleri.

The order Astragalo-Potentilletalia (Micevski 1971) and alliance Trifolion cherleri (Micevski 1972) that comprises the vegetation of dry grassland on siliceous, have been described on the territory of Macedonia. Many elaboration of this vegetation exist over the wider area of the southern Balkans (Micevski 1970, 1972, 1973, 1977, 1978, 1994, Horvatić \& Randjelović 1973, Randjelović 1975, Rexhepi 1979, Randjelović \& Ružić 1982, 1986, Ružić 1983, Micevski \& Matevski 1984, Konstantinou 1992, Matevski \& Kostadinovski 1998, Matevski et al. 2007, Sopotlieva \& Apostolova 2007, Bergmeier 2009, Čarni et al. 2010).

Five associations have been described in Macedonia so far, Tunico-Trisetetum myrianthi Micevski 1972 (in the region of Gevgelija and Bitola), Helianthemo-Euphorbietum thessalae Micevski 1973 (in the region of Kočani, Prilep, Veles and Makedonska Kamenica), Erysimo-Trifolietum Micevski 1977 (in the region of Skopje, Radoviš, Štip, Probištip, Kratovo and Veles), Diantho-Cistetum incani Micevski et Matevski 1984 (in the region of Gevgelija) and Biserrulo-Scleranthetum dichotomae Matevski et Kostadinovski 1998 (in the Mariovo region).

Here we deal with the dry grassland communities of Erysimo-Trifolietum, which develops on siliceous bedrock up to $900 \mathrm{~m}$. It is widespread in the central, northern and northeastern part of the Republic of Macedonia (Micevski 1977).

The aim of the article is to identify the position of newly acquired data of dry grassland vegetation in the eastern part of the Republic of Macedonia. After syntaxonomic classification of data within the association Erysimo-Trifolietum, we investigated its floristic, phytogeographical and structural diversity, as well as its detailed distribution pattern. Finally, we describe new syntaxa and discuss the classification of dry grasslands in the southern Balkans.

\section{MATERIALS AND METHODS}

During 2004 and 2005, field studies were conducted on many dry grassland localities in the region of Kratovo, on both sides of the River Kriva. We collected 81 vegetation samples (relevés) with plot size $100 \mathrm{~m}^{2}$, inhomogeneous relevés are expelled, where mixture of silicate and carbonate plant appears, other are shown in Table 1. The average annual temperature for this region is $11.4{ }^{\circ} \mathrm{C}$, and the average annual rainfall is $728.4 \mathrm{~mm}$ (Lazarevski 1993).

Vegetation research was carried out according to the Braun-Blanquet approach (Braun-Blanquet 1964; Westhoff \& van der Maarel 1973). The nomenclature of plant species is according to Flora Europaea (Tutin et al. 1964-1993); Prodromus florae peninsulae Balcanicae (Hayek 1927-1933), Flora of the Republic of Macedonia (Micevski 1985, 1993, 1995, 1998, 2001, 2005), Flora of Bulgaria (Jordanov 1963-1979; Velchev 1982, Kozuharov 1992, 1995), Flora of the SR Serbia (Josifović 1970-1977), as well as many other monographs and floristic and taxonomic articles. The syntaxonomy and nomenclature of the new plant communities are in accordance with the International Code of Phytosociological Nomenclature (Weber al. 2000).

Vegetation relevés made in the field and from literature sources were entered in the Turboveg database (Hennekens et al. 2001). The combined values for the cover-abundance scale was transformed according to Van der Maarel (1979) for the purpose of numerical analysis. Classifications of relevés were made by the program PC-ORD 4 (McCune \& Mefford 1999) where Ward's, Flexible beta methods and the relative Euclidean distance were applied. Vegetation relevés were also analyzed by the computer program JUICE 6.4 
(Tichy 2006), whereby diagnostic species were determined using fidelity measure coefficients (Barkman 1979, Chytrý et al. 2002).

Life forms according to Raunkiaer (1934) were used for defining the biological spectrum. Geoelements were established according to Gajić (1980) and Pignatti (2005). The proportion of therophytes and hemicryptophytes was visualised by a Mean plot diagram in the computer program Statistica 7.0. (StatSoft, 2007).

The results of numerical analysis were used to elaborate an analytic table (Table 1). All plant taxa appearing in the relevés were classified into the corresponding syntaxa. The basis for this classification was a synthetic table (not shown in the article), including the calculation of fidelity measurements, and expert knowledge.

The basic soil properties (soil type, $\mathrm{pH}$ and $\mathrm{CaCO}_{3}$ concentration) were analyzed and determined. The $\mathrm{pH}$ value of the soil solution was electrometrically determined with a glass electrode in water suspension and $1 \mathrm{M} \mathrm{KCl}$, while the carbonate concentration in the soil was determined by Scheibler's volumetric method (Mitrićeski et al. 2001).

\section{RESULTS}

We first made a cluster analysis with the formed database, which consists of 257 vegetation relevés. The results are presented as a dendrogram (Figure 1). It can be seen that vegetation relevés made during of our investigations in the northern parts of the Republic of Macedonia (around in Kratovo region) are divided into two clusters (numbers 1 and 2) and they are mostly related to vegetation relevés of the ass. Erysimo-Trifolietum (cluster with ordinal number 3).

Our relevés show a floristic affinity to ErysimoTrifolietum and all nine diagnostic taxa proposed by Micevski (1977) appear; it was decided to classify the relevés under consideration into ErysimoTrifolietum.

The relevés classified within Erysimo-Trifolietum were elaborated separatly. The results are presented as a dendrogram (Figure 2), in which it can be seen that the vegetation relevés are grouped in four clusters. It was decided that these four groups represent independent syntaxa, i.e., subassociations of the association ErysimoTrifolietum, as typicum, onobrychidetosum, scleranthetosum and brachypodietosum.

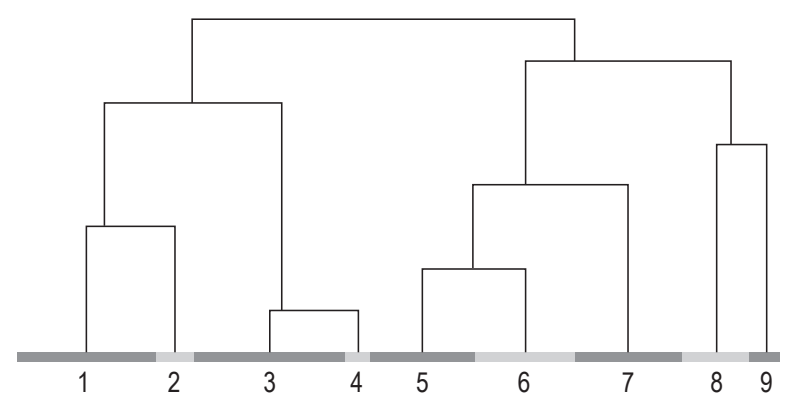

Figure 1: Dendrogram of hierarchical clustering of the vegetation relevés of the alliance Trifolion cherleri from the territory of the Republic of Macedonia in 9 clusters (flexible beta method, relative Euclidean distance). Legend: cluster 1 and cluster 2 - Erysimo-Trifolietum (Tab. I/1-25; II/26-53; III/1-32; Micevski, 1977); cluster 3 - Tab. 1/1-62 (own relevés) cluster 4- Tab. 1/63-72 (own relevés); cluster 5 and cluster 7 Helianthemo-Euphorbietum thessalae (literature data); cluster 6 -Tunico-Trisetetum myrianthi (literature data); cluster 8 - Biserrulo-Scleranthetum dichotomae (literature data); and cluster 9 - Diantho-Cistetum incani (literature data);

Slika 1: Dendrogram hierarhičnega kopičenja vegetacijskih popisov zveze Trifolion cherleri z ozemlja Republike Makedonije: 7 snopov (Wardova metoda, relativna evklidska razdalje). Legenda: snop 1 - Tabela 1/63-72 (lastni popisi); snop 2 - Tabela 1/1-62 (lastni popisi); snop 3 - Erysimo-Trifolietum (literaturni podatki); snop 4 - Tunico-Trisetetum myrianthi (literaturni podatki); snop 5 - Helianthemo-Euphorbietum thessalae (literaturni podatki); snop 6 - Biserrulo-Scleranthetum dichotomae (literaturni podatki); in snop 7 - DianthoCistetum incani (literaturni podatki).

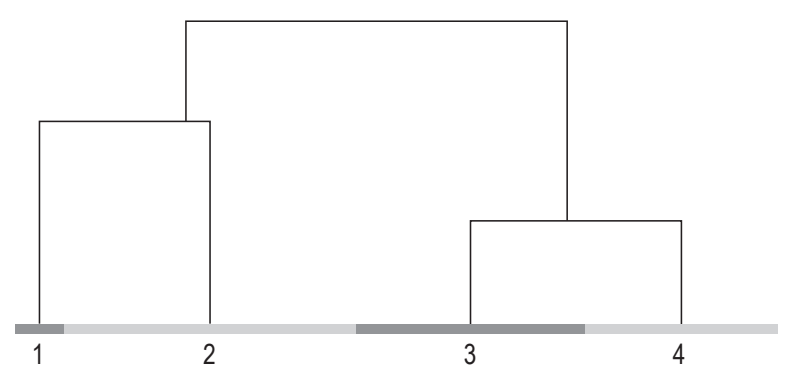

Figure 2: Dendrogram of hierarchical clustering of the vegetation relevés of the ass. Erysimo-Trifolietum Micevski 1977 on the territory of the Republic of Macedonia in four clusters (Ward's method, relative Euclidean distance); cluster 1 - Table 1/63-72 - Erysimo-Trifolietum brachypodietosum, cluster 2 Table 1/1-62 - Erysimo-Trifolietum scleranthetosum, cluster 3 - Erysimo-Trifolietum typicum, cluster 4 - Erysimo-Trifolietum onobrychidietosum.

Slika 2: Dendrogram hierarhičnega kopičenja vegetacijskih popisov asociacije Erysimo-Trifolietum Micevski 1977 z ozemlja Republike Makedonije: 4 snopi (Wardova metoda, relative Evklidska razdalja); snop 1 - Tabela 1/63-72 - Erysimo-Trifolietum brachypodietosum, snop 2 - Tabela 1/1-62 - ErysimoTrifolietum scleranthetosum, snop 3 - Erysimo-Trifolietum typicum, snop 4 - Erysimo-Trifolietum onobrychidietosum. 
The individuality of the four groups was also confirmed by calculation of differences in the biological spectrum (life forms) and phytogeographical structure (geoelements) (Table 3, 4). The difference in the presence of therophytes and hemicryptophytes in the four groups of relevés (subassociations) is statistically significant (Figure 3,4$)$. The spread of the relevés from the first to the fourth group is generally from north to south, by which the impact of continental climate is reduced and the impact of the sub-Mediterranean climate is increased. Therophytes, as the plants most adapted to arid conditions, appear in a dry and hot climate in which the vegetation period is shorter. It seems that the main difference between the subassociations is the proportion of therophytes and hemicryptopytes, which correlates to the geographical position and this is shown in the map of the distribution of the four subassociations (Figure 5).

Their biological and chorological spectra are presented in Tables 2 and 3.

Table 2: Biological spectrum of the subassociations of the ass. Erysimo diffusi-Trifolietum angustifolii Micevski 1977.

Tabela 2: Biološki spekter subasociacij asociacije Erysimo diffusi-Trifolietum angustifolii Micevski 1977.

\begin{tabular}{lccccc}
\hline life form (\%) & T & Ch & G & H & Ph \\
\hline subass. brachypodietosum & 53 & 40 & 2 & 4 & 1 \\
subass. scleranthetosum & 54 & 39 & 5 & 2 & 0 \\
subass. typicum & 56 & 38 & 3 & 3 & 0 \\
subass. onobrychietosum & 64 & 29 & 5 & 2 & 0 \\
\hline
\end{tabular}

Table 3: Chorological spectrum of the subassociations of the ass. Erysimo diffusi-Trifolietum angustifolii Micevski 1977.

Tabela 3: Horološki spekter subasociacij asociacije Erysimo diffusi-Trifolietum angustifolii Micevski 1977.

\begin{tabular}{|c|c|c|c|c|}
\hline Areal types $(\%)$ & 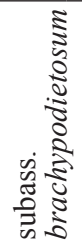 & 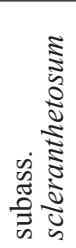 & 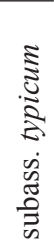 & 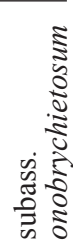 \\
\hline Eurasian & 37 & 34 & 30 & 32 \\
\hline Euromediterranean & 36 & 32 & 36 & 36 \\
\hline Stenomediterranean & 10 & 7 & 10 & 17 \\
\hline Mediterranean-mountain & 2 & 3 & 5 & 3 \\
\hline Balkanic and sub-Balkanic & 5 & 11 & 7 & 5 \\
\hline Boreal & 2 & 3 & 3 & 0 \\
\hline Cosmopolitan & 8 & 10 & 8 & 7 \\
\hline
\end{tabular}

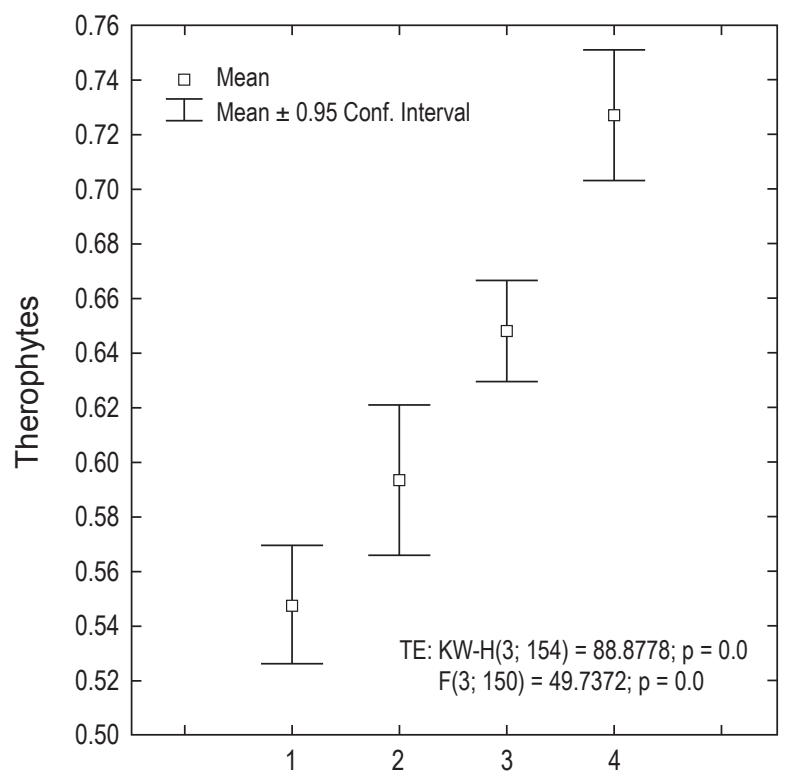

Figure 3: Mean plot diagram. Proportion of therophytes in groups of relevés (subassociations): 1 - subass. brachypodietosum, 2 - subass. scleranthetosum, 3 - subass. typicum and 4 - subass. onobrychietosum.

Slika 3: Diagram srednjih vrednosti. Delež terofitov v skupinah popisov (subasociacijah): 1 - subass. brachypodietosum, 2 - subass. scleranthetosum, 3 - subass. typicum in 4 - subass. onobrychietosum.

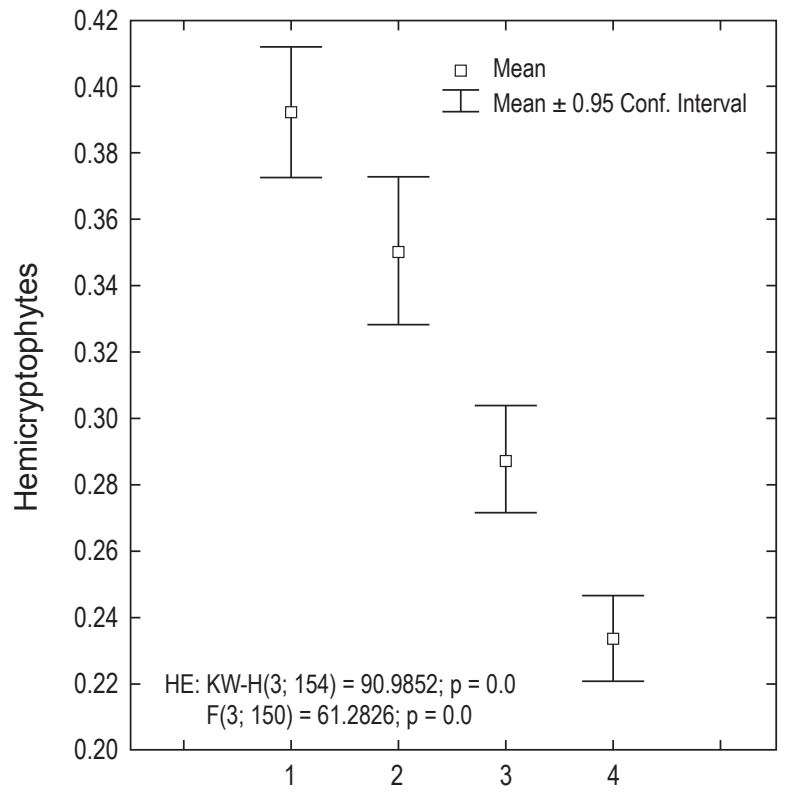

Figure 4: Mean plot diagram. Proportion of hemicryptophytes in groups of relevés (subassociations): 1 - subass brachypodietosum, 2 - subass. scleranthetosum, 3 - subass. typicum and 4 - subass. onobrychidietosum.

Slika 4: Diagram srednjih vrednosti. Delež hemikriptofitov v skupinah popisov (subasociacijah): 1 - subass. brachypodietosum, 2 - subass. scleranthetosum, 3 - subass. typicum in 4 - subass. onobrychietosum. 


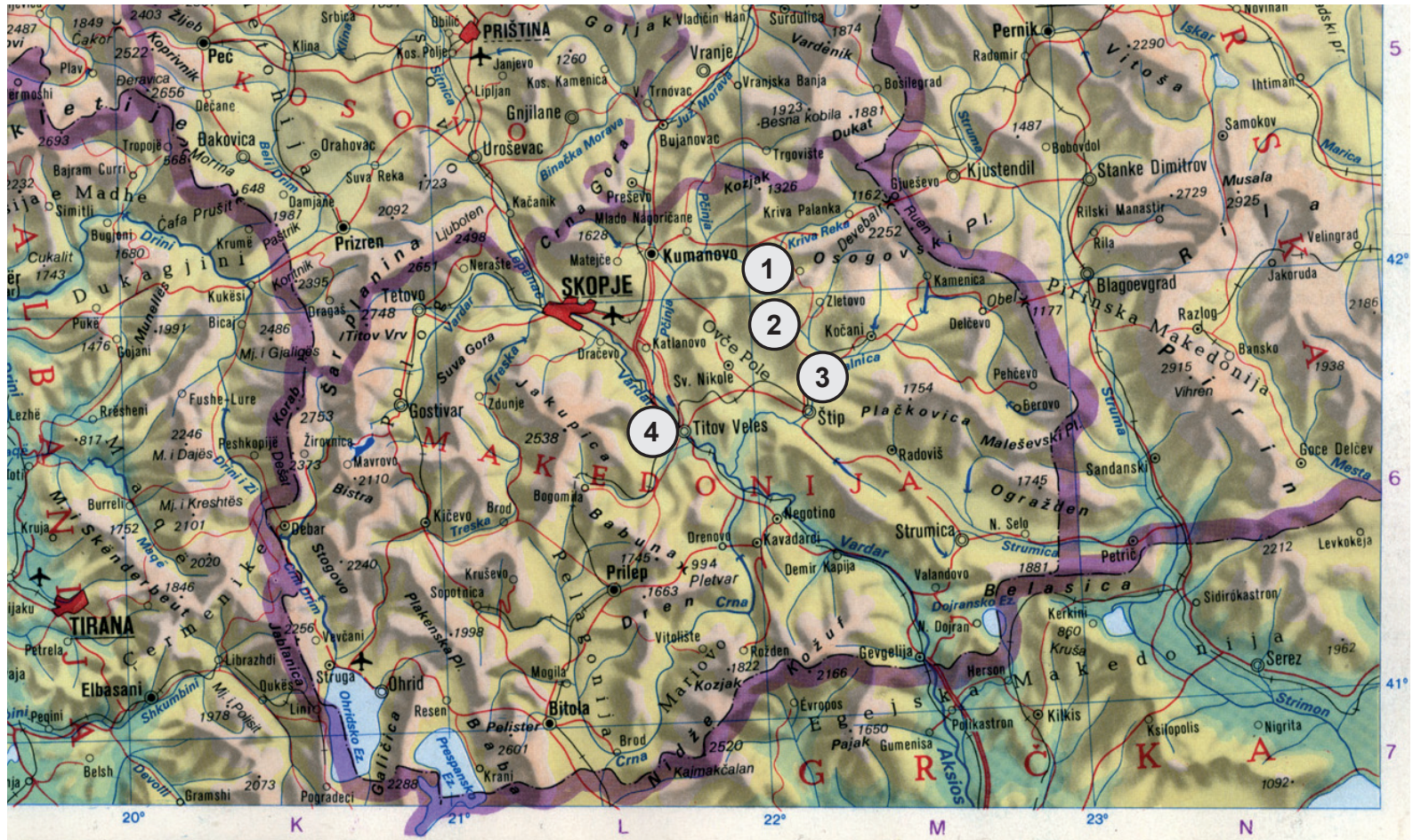

Figure 5: Distribution of the subassociations of the association Erysimo-Trifolietum, 1 - subass. brachypodietosum, 2 - subass. scleranthetosum, 3 - subass. typicum and 4 - subass. Onobrychietosum.

Slika 5: Razporeditev subasociacij associacije Erysimo-Trifolietum, 1 - subass. brachypodietosum, 2 - subass. scleranthetosum, 3 - subass. typicum in 4 - subass. onobrychietosum.

\section{DISCUSSION}

The results show that the vegetation of dry grasslands in the research area around Kratovo should be classified into the association Erysimo-Trifolietum Micevski 1977. Under the original syntaxonomic concept, it is part of the alliance Trifolion cherleri, which includes the community on rock and highland pastures on siliceous bedrock, in the order Astragalo-Potentiletallia and the class Festuco-Brometea (Micevski 1977).

The position of the alliance Trifolion cherleri in modern syntaxonomic systems is often defined differently from its original conception. Thus, according to Rodwell et al. (2002), which provides a review of phytocenological alliances and their correlation with EUNIS habitats, the alliance Trifolion cherleri is not part of the order AstragaloPotentilletalia and the class Festuco-Brometea but within the order Helianthemetalia guttati Br.-Bl. in Br.-Bl. et al. 1940, from the class Helianthemetea guttati (Br.-Bl. in Br.-Bl. et al. 1952) Rivas Goday et Rivas-Mart. 1963.

This new syntaxonomic solution is accepted by Sopotlieva \& Apostolova (2007) and the first time they register the ass. Erysimo-Trifolietum on the territory of the Republic of Bulgaria, they place it in the class Helianthemetea guttati.

The problem of the syntaxonomic position of the alliance Trifolion cherleri described on the territory of the Republic of Macedonia (represented by five associations also described from its territory) is still an open question. A definitive solution requires extensive research into its broader areal, based on the most recent findings presented in the works of Royer (1991), Mucina (1997), Rodwell et al. (2002) and others. In this paper, we adhere to the syntaxonomy within the frame of the class Festuco-Brometea, in which have been subordinated community from the belt of mountain pastures in the territory of the Republic of Macedonia.

According to the results of analysis within the frame of the ass. Erysimo-Trifolietum from northeastern parts of the Republic of Macedonia, two new well- separated subassociations can be distinguished, we propose the following syntaxonomic scheme of the association: 
Class: Festuco-Brometea Br. Bl. et Tx. 1943

Order: Astragalo - Potentilletalia Micevski 1971

Alliance: Trifolion cherleri Micevski 1971

ass. Erysimo diffusi-Trifolietum angustifolii Micevski 1977

(Table 1 (Micevski 1977), lectotypus hoc loco: relevé no. 9)

- subass. typicum Micevski 1977

- subass. onobrychietosum Micevski 1977

(Table 3 (Micevski 1977), lectotypus hoc loco: relevé no. 14)

- subass. scleranthetosum subass. nova

- subass. brachypodietosum subass. nova

\section{Erysimo diffusi-Trifolietum angustifolii scleran-} thetosum subass. nova

(Table 1, relevés 1-62, holotypus hoc loco: relevé no. 11)

Registered at several locations around Kratovo, at $453-735 \mathrm{~m}$ height, inclination up to $10^{\circ}$, in fields with different aspects (mostly with a southern aspect) (Figure 6).

The differential species of the subassociation scleranthetosum are Logfia arvensis, Scleranthus perennis subsp. dichotomus, Sedum hispanicum, Verbascum lesnovoensis, Trifolium retusum, Valerianella turgida and Elymus hispidus subsp. hispidus.

The results of chemical analysis of soil samples taken from the soil profile on a representative vegetation relevé are shown in Table 4.

Table 4: Soil type results and $\mathrm{pH}$.

Tabela 4: Tipi tal in $\mathrm{pH}$.

\begin{tabular}{llllccc}
\hline $\begin{array}{l}\text { Serial } \\
\text { No. }\end{array}$ & $\begin{array}{l}\text { Soil } \\
\text { type }\end{array}$ & $\begin{array}{l}\text { Horizon and } \\
\text { depth (cm) }\end{array}$ & Locality & \multicolumn{2}{c}{$\mathrm{CaSO}_{3}$} & \multicolumn{2}{c}{$\mathrm{pH}$} \\
$(\%)$ & & $\mathrm{H}_{2} \mathrm{O}$ & nKCl \\
\hline 1 & leptosol & (A) $0-5$ & v. Kuklica-Vidim & 0 & 7.5 & 6.4 \\
2 & leptosol & (A) $0-10$ & v. Filipovci & 0 & 6.9 & 5.4 \\
3 & leptosol & (A) $0-8$ & v. Konju & 0 & 7.1 & 5.8 \\
\hline
\end{tabular}

In the researched leptosols, because of the shallow solum, supplying the plants with water and nutrients is obstructed and the habitats must therefore be considered extremely xerothermic. The profile with serial number 1 is particularly xerothermic.

Stands of the subass. scleranthetosum were registered on very eroded habitats, so they contain many xerothermic species that are specific to that type of habitat (Scleranthus perennis subsp. dichotomus, Sedum annuum, Sedum hispanicum, Sedum sartorianum, Sedum rubens, Valerianella turgida, Minuartia hirsuta subsp. falcata, Psilurus incurvus,

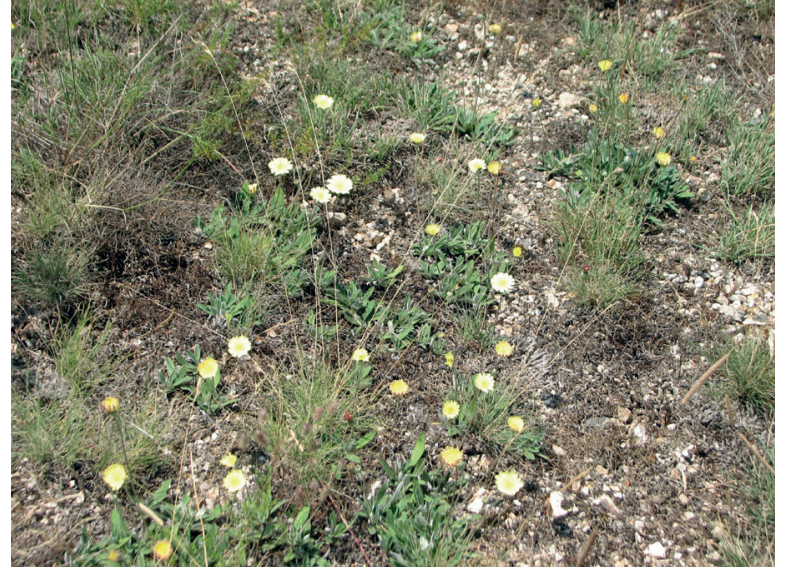

Figure 6: Location of the investigated area (village Pendać). Slika 6: Lokaliteta na raziskovanem območju (vas Pendać).

Poa bulbosa, Eragrostis minor, Vulpia ciliata, Logfia arvensis and others), which determine the physiognomy of the plant cover.

The communities representing the subass. scleranthetosum contain 250 plant species. Their biological and chorological spectra are presented in Table 2 and 3.

From the analysis of the floristic composition and percentage incidence of the life forms, it is obvious that this is a typical sub-Mediterranean community. The large percentage incidence of therophytes (54\%) is in direct correlation with the influence of the modified sub-Mediterranean climate. The chorological spectrum in the studied areas shows great phytogeographic diversity.

\section{Erysimo diffusi-Trifolietum angustifolii brachy- podietosum subass. nova}

(Table 1, relevés. 63-72, Holotypus hoc loco: relevé no. 66)

The floristic composition of the community in the area is very rich and is shown in Table 1.

The subassoaciation is clearly differentiated and is characterized by the following species Minuartia hamata, Brachypodium distachyon, Echinaria capitata, Ziziphora capitata, Linum corymbulosum, Coronilla scorpioides, Buffonia tenuifolia and Dianthus pallens.

According to the chemical analysis of soil samples taken from representative relevés of the researched areas, the soil reaction in $\mathrm{H}_{2} \mathrm{O}$ is $\mathrm{pH}-$ 6.6, and in $\mathrm{nKCl}$ is 5.4 .

Based on the American classification of soil reaction in water specified by Filipovski (1984), the soil of this locality has a neutral reaction.

The alliance Trifolion cherleri is poorly char- 
acterized and is represented with several taxa Taeniatherum caput-medusae, Galium macedonicum and Aphanes arvensis. This is probably the result of the large number of calcifilic species that have found favourable conditions for development within the subassociation and they have probably outcompeted most of the characteristic species of the alliance Trifolion cherleri.

The presence of many calcifilic species is specific for the researched stands of this subassociation around Kratovo, although there is a lack of limestone as a geological substrate. This could be explained by the influence of limestone from the deeper soil layers or the presence of limestone as a geology substrate in the surroundings.

The communities representing the subass. brachypodietosum contain 162 plant species. Their biological and chorological spectra are presented in Table 2 and 3.

From analysis of the floristic composition and percentage incidence of life forms, this is obviously a typical sub-Mediterranean community. The group of Mediterranean areal types (StenoMediterranean, Euromediterranean, and Mediterranean-mountain) is dominant and provides a strong sub-Mediterranean imprint to the vegetation of the researched area. This group is represented by 48 percent and usually inhabits theroxerophylous habitats.

\section{ACKNOWLEDGEMENTS}

We are grateful to the Macedonian Academy of Sciences and Arts for financial support of the research. The authors acknowledge also the financial support from the Slovenian Research Agency (projects No L1-9737, P1-0236). R. Ć. is grateful to the Institute of Biology, Scientific Research Centre of the Slovenian Academy of Sciences and Arts to get opportunity to work at the institute. Thanks to Marjan Andreevski for help with pedological analysis.

\section{REFERENCES}

Bergmeier, E., Konstantinou M., Tsiripidis I. \& Sýkora K. 2009: Plant communities on metalliferous soils in northern Greece. Phytocoenologia 39: 411-438.

Barkman, J.J. 1989: Fidelity and character-species, a critical evaluation. Vegetatio 85: 105-116.
Braun-Blanquet, J., Molinier, R. \& Wagner, H. 1940: Prodrome des groupements végétaux. Prodromus der Pflanzengesellschaften. CistoLavanduletea (landes siliceuses à cistes et lavandes). Montpellier. $53 \mathrm{pp}$.

Braun-Blanquet, J. \& Tüxen, R. 1943: Übersicht der höheren Vegetationseinheiten Mitteleuropas. Commun. Stat. Int. Géobot. Médit. et Alpin 84: 1-11.

Braun-Blanquet, J., Roussine, N. \& Nègre, R. 1952: Les groupements végétaux de la France Méditerranéenne. Centre National de la Recherche Scientifique. Montpellier.

Braun-Blanquet, J. 1964: Pflanzensoziologie. Grundzüge der Vegetationskunde. 3. ed. Springer Verlag. Wien. 865 pp.

Chytrý, M., Tichý, L., Holt, J., \& Botta-Dukát, Z. 2002: Determination of diagnostic species with statistical fidelity measures. Journal of Vegetation Science 13: 79-90.

Čarni, A., Košir, P., Karadžić, B., Matevski, V., Redžić, S. \& Škvorc, Ž. 2009: Thermophilous deciduous forests in Southeastern Europe. Plant Biosystems 143: 1-13.

Čarni, A., Matevski, V. \& Šilc, U. 2010: Morphological, chorological and ecological plasticity of Cistus incanus in the southern Balkans. Plant Biosystems 144: 602-617.

Dostalek, J. \& Frantik, T. 2008: Dry grassland plant diversity conservation using low-intensity sheep and goat grazing management: case study in Prague (Czech Republic). Biodiversity and Conservation 17: 1439-1454.

Dzwonko, Z. \& Loster, S. 2007: A functional analysis of vegetation dynamics in abandoned and restored limestone grasslands. Journal of Vegetation Science 18: 203-212.

Filipovski, Gj. 1984: Pedologija. Treto izdanie. Univerzitet Sv. Kiril i Metodij, Skopje

Gajić, M. 1980: Pregled vrsta flore SR Srbije sa biljno-geografskim oznakama. Glasnik Šumarskog Fakulteta, "A" "Šumarstvo" (Beograd). 54: 111-140.

Hayek, A. 1924-1933: Prodromus florae peninsulae Balcanicae. I-III. Dachlem bei Berlin.

Hennekens, S.M. \& Schaminée, J.H.J. 2001: TURBOVEG, a comprehensive database management system for vegetation data. Journal of Vegetation Science 12: 589-591.

Hill, M. O. 1979: TWINSPAN. A Fortran program for arranging multivariate data in an ordered two-way table by classification of the individuals and attributes. Cornell University, Ithaca, $66 \mathrm{pp}$. 
Jordanov, D.(ed.). 1963-1979: Flora Republicae Popularis Bulgaricae, Vol. 1-7. In Aedibus Acad. Sci. Bulgaricae, Serdicae (in Bulgarian) Josifović, M. et al. 1970-1986: Flora SR Srbije, I - X, SANU, Beograd.

Kavgaci, A., Čarni, A., Tecimen, B. \& Ozlap, G. 2010: Diversity and ecological differentiation of oak forests in NW trace (Turkey). Archives of Biological Sciences 62: 707-720.

Kiehl, K. \& Pfadenauer, J. 2007: Establishment and persistence of target species in newly created calcareous grasslands on former arable fields. Plant Ecology 189: 31-48.

Konstantinou, M. 1992: Phytosociological studies of the vegetation on metalliferous soils, in northern Greece, Institute of Systematic Botany and Phytogeography, Dept. Botany, Aristotle University, Thessaloniki.

Kozhuharov. S. (ed.). 1995: Flora Republicae Popularis Bulgaricae. Vol. 10. In Aedibus Acad. Sci. Bulgaricae, Serdicae (in Bulgarian)

Kuneš, P., Pelánková, B., Chytrý, M., Janovská, V., Pokorný, P. \& Petr, L. 2008: Interpretation of the last-glacial vegetation of eastern-central Europe using modern analogues from southern Siberia. Journal of Biogeography 35: 2223-2236.

Lazarevski, A. 1993: Klimata vo Makedonija. Kultura, Skopje, 282 pp.

Matevski, V. \& Kostadinovski, M. 1998: BiserruloScleranthetum dichotomae Matevski et Kostadinovski ass. nova vo vegetacijata na brdskite pasišta vo Republika Makedonija. God. zb. biol. 51: 25-35.

McCune, B. \& Mefford, M. J. 1999: PC-ORD. Multivariate analysis of ecological data, Version 4.0. MjM Software Design, Gleneden Beach, 237 pp.

Micevski, K. 1970: Astragalo-Potentilletalia, nov vegetaciski red na brdskite pasišta vo Makedonija. Prilozi MANU, Odd. za prir. mat. nauki 2(2): 15-23.

Micevski, K. 1972: Tunico-Trisetetum myrianthi Micevski ass. nova vo vegetacijata na brdskite pasišta vo Makedonija. God. zb. PMF-biol. 24: 59-65.

Micevski, K. 1973: Helianthemo-Euphorbietum thessalae Micevski ass. nova vo vegetacijata na brdskite pasišta vo Makedonija. God. zb. PMF - biol. 25: 149-155.

Micevski, K. 1977: Erysimo-Trifolietum Micevski ass. nova vo vegetacijata na Makedonija. Prilozi MANU, Odd. za prir. mat. nauki 9(1): 75-82.
Micevski, K. 1985: Flora na SR Makedonija I/1. MANU, Skopje.

Micevski, K. 1993: Flora na Republika Makedonija I/2. MANU, Skopje.

Micevski, K. 1994: Vegetation of Mt. Bistra. MANU, Skopje, pp. 1-91.

Micevski, K. 1995: Flora na Republika Makedonija I/3. MANU, Skopje

Micevski, K. 1996: Verbascum lesnovoensis Micevski spec. nov. vo florata na Republika Makedonija. Prilozi MANU, Odd. biol. med. nauki 17(1-2): 17-24.

Micevski, K. 1998: Flora na Republika Makedonija I/4. MANU, Skopje.

Micevski, K. 2001: Flora na Republika Makedonija I/5. MANU, Skopje.

Micevski, K. 2005: Flora na Republika Makedonija I/6. MANU, Skopje.

Micevski, K. \& Matevski, V. 1984: Diantho-Cistetum incani Micevski et Matevski ass. nova vo vegetacijata na SR Makedonija. Prilozi MANU, Odd. biol. med. nauki 5(2): 11-16, Skopje.

Mitrićeski, J. \& Mitkova, T. 2001: Praktikum po pedologija. Univerzitet Sv. Kiril i Metodij Zemjodelski fakultet, Skopje, 1-165 pp.

Mucina, L. 1997: Conspectus of classes of European vegetation. Folia Geobotanica et Phytotaxonomica 32: 117-172.

Pignatti, S. 2005: Valori di bioindicazione delle piante vascolari della flora d'Italia. BraunBlanquetia 39: 1-98.

Raunkier, C. 1934: The life forms of plants and statistical plant geography. Clarendon, Oxford.

Redžepi, F. 1979: Ekološke prilike i razvoj zajednice Echinario-Convolvuletum althaeoides ass. nova na Kosovu. Drugi kongres ekologa Jugoslavije. Savez društava ekologa Jugoslavije 2, Zadar- Plitvice, pp. 1031-1036.

Redžić, S. 2007: The syntaxonomy of the vegetation of the continental Dinaric Alps (W. Balkans). Collection of papers devoted to academician Kiril Micevski, MASA, Skopje, 249$280 \mathrm{pp}$.

Rivas Goday, S. \& Rivas-Martínez, S. 1963: Estudio y clasificación de los pastizales españoles. Publ. Ministerio de Agricultura. Madrid.

Rivas-Martinez, S. 1978: Sur la syntaxonomie des pelouses thérophytiques d'Europe occidentale. Colloques Phytosociologiques 6: 55-69.

Rodwell, J., Schaminée, J., Mucina, L., Pignatti, S., Dring. J. \& Moos, D. 2002: The Diversity of European Vegetation. An overview of phytosociological alliances and their relationships 
to EUNIS habitats. Wageningen, NL. Report EC-LNV nr. 2002/054.

Royer, J. M. 1991: Synthèse eurosibérienne, phytosociologique et phytogèographique de la classe des Festuco-Brometea. Dissertationes Botanicae 178: 1-296.

Ružić, M. 1983: Asocijacija Festuco-Chrysopogonetum grylli Randj. 74 na planini Vidojevići kod Prokuplja. Glasnik Prirodnjačkog Muzeja (Beograd), Ser. B 38: 47-54.

Sopotlieva, D. \& Apostolova, I. 2007: The association Erysimo-Trifolietum Micevski 1977 in Bulgaria and some remarks on its Mediterranean character. Hacquetia 6(2): 131-141.

StatSoft, Inc. 2005: STATISTICA (data analysis software system). Version 7. - URL [http:// www.statsoft.com].

Ter Braak, C. J. F. \& Šmilauer, P. 2002: CANOCO Reference Manual and CanoDraw for Windows User's Guide: Software for Canonical Community Ordination (version 4.5). Microcomputer Power (Ithaca NY, USA).

Tichý, L. 2002: JUICE, software for vegetation classification. Journal of Vegetation Science 13: 451-453.

Tutin, T.G. et al. [ed.] 1964-1993: Flora Europaea, 1-5, Cambridge University Press.

Van der Maarel, E. 1979: Transformation of cov- er-abundance values in phytosociology and its effects of community similarity. Vegetatio 39 (2): 97-114.

Velchev, V. (ed.). 1982: Flora Republicae Popularis Bulgaricae. Vol. 8. In Aedibus Acad. Sci. Bulgaricae. Serdicae (in Bulgarian)

Velchev, V. (ed.). 1989: Flora Republicae Popularis Bulgaricae. Vol. 9. In Aedibus Acad. Sci. Bulgaricae. Serdicae (in Bulgarian)

Velev N.I. \& Apostolova I.I. 2009: A review of Potentillo ternatae-Nardion strictae alliance. Hacquetia 8: 49-66.

Wagner V. 2009: Eurosiberian meadows at their southern edge: patterns and phytogeography in the NW Tien Shan. Journal of Vegetation Science 20: 199-208.

Walter H. \& Straka H. 1970: Arealkunde. Floristisch-historische Geobotanik. Einführung die Phytologie, V. Eugen Ulmer, Stuttgart, Germany. III/2, $478 \mathrm{p}$.

Weber, H, E., Moravec, J. \& Theurillat, J.-P. 2000: International Code of Phytosociological Nomenclature. 3 ed. Journal of Vegetation Science 11 (5): 739-768.

Westhoff, V. \& van der Maarel, E. 1973: The BraunBlanquet approach. In: Whittaker R. H. (ed.): Ordination and classification of communities, Dr. W. Junk Publ., The Hague. p. 619-737. 


\section{APPENDIX}

Localities of the reléves and cover of the layers in Table 1. Running number, locality aspect, altitude (m), cover, inclination (\%), latitude, longitude, and sampling date are presented, respectively.'"

1: Ketenovo, E, 431, 79, 24, $42^{\circ} 6^{\prime} 32.31^{\prime \prime} \mathrm{N}, 22^{\circ}$ 5' 4.05" E, 28. 05. 2004; 2: Ketenovo, E, 459, 82, $30,42^{\circ} 6^{\prime} 36.65^{\prime \prime} \mathrm{N}, 22^{\circ} 5^{\prime} 4.07^{\prime \prime} \mathrm{E}, 28.05 .2004$; 3: Ketenovo, NE, 478, 83, 17, 42 ${ }^{\circ} 6^{\prime} 36.51^{\prime \prime} \mathrm{N}, 2^{\circ} 5^{\prime}$ 2.79" E, 28. 05. 2004; 4: Pendać, SW, 590, 87, 6, $42^{\circ}$ 6' 50.42" N, $22^{\circ} 0$ 0' 58.86" E, 05. 06. 2004; 5: Pendać, SE, 593, 78, 8, 42 ${ }^{\circ} 6^{\prime} 55.98^{\prime \prime} \mathrm{N}, 2^{\circ} 0^{\prime} 50.57^{\prime \prime} \mathrm{E}, 05$. 06. 2004; 6: Pendać, SW, 665, 91, 4, $42^{\circ} 7$ ' 11.30" N, $22^{\circ}$ 0' 57.03" E, 06. 06. 2004; 7: Pendać, SW, 652, 97, 3, 42 7' 6.95" N; $22^{\circ} 0^{\prime}$ 47.04" E, 06. 06. 2004;

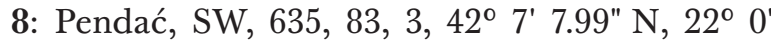
29.22" E, 06. 06. 2004; 9: Filipovci, E, 544, 98, $6,42^{\circ} 3^{\prime} 16.00^{\prime \prime} \mathrm{N}, 22^{\circ} 4^{\prime} 45.01^{\prime \prime} \mathrm{E}, 09$. 06. 2004; 10: Filipovci, S, 548, 89, 3, $42^{\circ} 3^{\prime} 16.49^{\prime \prime} \mathrm{N}, 2^{\circ}$ 4' 46.14" E, 09. 06. 2004; 11: Filipovci, SW, 569, 78, 4, $42^{\circ} 3^{\prime} 16.05^{\prime \prime} \mathrm{N} ; 22^{\circ} 4^{\prime} 51.46^{\prime \prime} \mathrm{E}, 10.06 .2004$; 12: Filipovci, W, 575, 98, 420 $3^{\prime} 15.18^{\prime \prime} \mathrm{N}, 2^{\circ} 4^{\prime}$ 53.67" E, 09. 06. 2004; 13: Filipovci, N, 578, 100, $2,42^{\circ} 3^{\prime} 17.31^{\prime \prime} \mathrm{N}, 22^{\circ} 4^{\prime} 55.65^{\prime \prime} \mathrm{E}, 10.06 .2004 ; 14$ : Filipovci, W, 561, 100, 1, 42 ${ }^{\circ} 3^{\prime} 21.08^{\prime \prime} \mathrm{N}, 2^{\circ} 4^{\prime}$ 52.91" E, 10. 06. 2004; 15: Š. Rudare, SW, 417, 100, $3,42^{\circ} 4^{\prime} 47.56^{\prime \prime} \mathrm{N}, 2^{\circ} 59^{\prime} 18.90^{\prime \prime} \mathrm{E}, 07.06 .2004 ; \mathbf{1 6}$

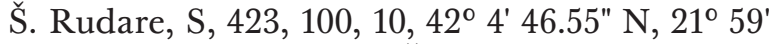
20.93" E, 10. 06. 2004; 17: Š. Rudare, SE, 445, 100, 9, $42^{\circ} 4^{\prime} 41.93 " \mathrm{~N}, 2^{\circ} 59^{\prime} 30.47^{\prime \prime} \mathrm{E}, 10.06 .2004 ; 18$ :

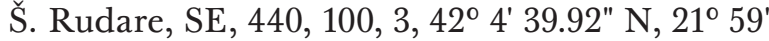
32.24" E, 13. 06. 2004; 19: Š. Rudare, SE, 433, 98, $8,42^{\circ} 4^{\prime} 38.46^{\prime \prime} \mathrm{N}$; $21^{\circ} 59^{\prime} 34.17^{\prime \prime} \mathrm{E}, 13.06 .2004 ; 20$ : Š. Rudare, W, 421, 92, 12, $42^{\circ} 4^{\prime} 53.82^{\prime \prime} \mathrm{N}, 2^{\circ} 59^{\prime}$ 18.77" E, 13. 06. 2004; 21: Š. Rudare, SW, 441, 100, $10,42^{\circ} 4^{\prime} 52.62^{\prime \prime} \mathrm{N}, 2^{\circ} 59^{\prime} 22.94 " \mathrm{E}, 13.06 .2004$; 22: Ketenovo, N, 454, 84, 13, $42^{\circ} 6^{\prime} 51.75^{\prime \prime} \mathrm{N}$; $22^{\circ}$ 5' 1.21" E, 29. 05. 2004; 23: Ketenovo, NW, 427, $96,17,42^{\circ} 6^{\prime} 50.34^{\prime \prime} \mathrm{N}, 22^{\circ} 5^{\prime} 7.30^{\prime \prime} \mathrm{E}, 29.05 .2004$; 24: Kuklica, W, 678, 100, 11, $42^{\circ} 6^{\prime} 2.97^{\prime \prime} \mathrm{N}, 22^{\circ} 1^{\prime}$ 5.12" E, 31. 05. 2005; 25: Kuklica, N, 413, 100, 15, $42^{\circ} 5^{\prime} 3.75^{\prime \prime} \mathrm{N}, 22^{\circ} 1^{\prime} 6.56^{\prime \prime} \mathrm{E}, 31$. 05. 2005; 26: Kuklica, N, 427, 100, 3, 42 ${ }^{\circ} 5^{\prime} 4.58^{\prime \prime} \mathrm{N}, 22^{\circ} 1^{\prime} 18.57^{\prime \prime} \mathrm{E}$, 31. 05. 2005; 27: Kuklica, S, 395, 100, 1, $42^{\circ} 4^{\prime}$ $59.40^{\prime \prime} \mathrm{N}, 22^{\circ} 1^{\prime}$ 24.93" EE, 03. 06. 2005; 28: Kuklica, NE, 401, 100, 1, 42 ${ }^{\circ} 5^{\prime} 2.27^{\prime \prime} \mathrm{N}, 22^{\circ} 1^{\prime} 24.85^{\prime \prime} \mathrm{E}$, 03. 06. 2005; 29: Kuklica, E, 404, 100, 5, $42^{\circ}{ }^{\circ}$ 1.31" N, $22^{\circ} 1^{\prime}$ 23.20" E, 03. 06. 2005; 30: Kuklica, S, 598, 97, 3, 42 ${ }^{\circ} 5^{\prime} 40.08^{\prime \prime} \mathrm{N}, 22^{\circ} 1^{\prime} 34.89^{\prime \prime} \mathrm{E}$, 28. 05. 2005; 31: Kuklica, SE, 678, 98, 15, $42^{\circ} 5^{\prime}$
43.80" N, $22^{\circ} 1^{\prime}$ 48.88" E, 28. 05. 2005; 32: Kuklica, S, 765, 100, 17, $42^{\circ} 6^{\prime} 22.25^{\prime \prime} \mathrm{N}, 2^{\circ} 1^{\prime} 32.11^{\prime \prime} \mathrm{E}$, 29. 05. 2005; 33: Kuklica, SW, 705, 72, 5, $42^{\circ} 5^{\prime}$ 49.71" N, $22^{\circ}$ 1' 39.49" E, 28. 05. 2005; 34: Kuklica, NE, 698, 75, 8, 42 ${ }^{\circ} 6^{\prime} 6.78^{\prime \prime} \mathrm{N}, 22^{\circ} 1^{\prime} 39.76^{\prime \prime} \mathrm{E}$, 28. 05. 2005; 35: Kuklica, S, 660, 68, 4, $42^{\circ} 5^{\prime}$ $57.40 " \mathrm{~N}, 22^{\circ} 1^{\prime} 12.54 " \mathrm{E}$, 29. 05. 2005; 36: Kuklica, $\mathrm{S}, 650,74,3,42^{\circ} 5^{\prime} 55.95^{\prime \prime} \mathrm{N}, 22^{\circ} 1^{\prime} 12.29 " \mathrm{E}, 29$. 05. 2005; 37: Kuklica, S, 719, 78, 5, $42^{\circ} 6^{\prime} 5.52^{\prime \prime} \mathrm{N}$, $22^{\circ} 1^{\prime}$ 10.10" E, 29. 05. 2005; 38: Kuklica, E, 727,

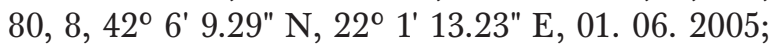
39: Kuklica, SE, 745, 80, 4, $42^{\circ} 6^{\prime} 20.84^{\prime \prime} \mathrm{N}, 22^{\circ}$ 1' 17.13" E, 01. 06. 2005; 40: Kuklica, E, 741, 100, $25,42^{\circ} 6^{\prime} 35.53^{\prime \prime} \mathrm{N}, 2^{\circ} 1^{\prime} 39.11^{\prime \prime} \mathrm{E}, 29$. 05. 2009; 41: Kuklica, E, 535, 95,12, $42^{\circ} 5^{\prime} 34.38^{\prime \prime} \mathrm{N}, 2^{\circ} 1^{\prime}$ 31.14" E, 05. 06. 2005; 42: Kuklica, N, 541, 98, 7, $42^{\circ}$ 5' 37.42" N, $22^{\circ} 1^{\prime} 12.30 "$ E, 05. 06. 2005; 43: Kuklica, $\mathrm{S}, 390,68,5,42^{\circ} 4^{\prime} 56.03^{\prime \prime} \mathrm{N}, 22^{\circ} 1^{\prime} 17.31^{\prime \prime} \mathrm{E}$, 01. 06. 2005; 44: Kuklica, SE, 387, $72,10,42^{\circ} 4^{\prime}$ 56.00" N, $22^{\circ} 1^{\prime}$ 23.00" E, 01. 06. 2005; 45: Kuklica, E, 396, 96, 9, $42^{\circ} 5^{\prime} 0.46^{\prime \prime} \mathrm{N}, 22^{\circ} 1^{\prime} 25.30^{\prime \prime} \mathrm{E}, 01.06$. 2005; 46: Kuklica, S, 387, 67, 5, 42 4' 56.00" N, $22^{\circ} 1^{\prime}$ 5.00" E, 31. 05. 2005; 47: Kuklica, S, 400, 69, 7, 42 4' 59.00" N, $22^{\circ} 1^{\prime}$ 6.00" E, 31. 05. 2005; 48: Kuklica, S, 406, 72, 9, $42^{\circ} 5^{\prime} 2.00^{\prime \prime} \mathrm{N}, 22^{\circ} 1^{\prime}$ 5.00" E, 31. 05. 2005, 04. 06. 2005; 49: Kuklica, S, $472,62,15,42^{\circ} 5^{\prime} 26.00^{\prime \prime} \mathrm{N}, 22^{\circ} 1^{\prime} 17.00^{\prime \prime} \mathrm{E}, 01.06$. 2005; 50: Kuklica, SW, 476, 78, 9, $42^{\circ} 5^{\prime} 28.23^{\prime \prime} \mathrm{N}$, $22^{\circ} 1^{\prime} 10.35 "$ E, 04. 06. 2005; 51: Kuklica, S, 480, $86,9,42^{\circ} 5^{\prime} 27.19^{\prime \prime} \mathrm{N}, 2^{\circ} 1^{\prime} 15.26^{\prime \prime} \mathrm{E}, 04.06 .2005$; 52: Kuklica, SW, 487, 80, 5, $42^{\circ} 5^{\prime} 28.09^{\prime \prime} \mathrm{N}, 22^{\circ}$ 1' 20.79" E, 04. 06. 2005; 53: Kuklica, S, 502, 90, $10,42^{\circ} 5^{\prime} 30.00^{\prime \prime} \mathrm{N}, 2^{\circ} 1^{\prime} 29.00^{\prime \prime} \mathrm{E}, 04.06 .2005$;

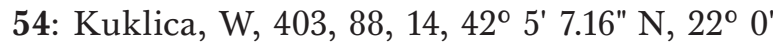
34.46" E, 05. 06. 2005; 55: Kuklica, S, 398, 86, 15, $42^{\circ} 5^{\prime}$ 7.02" N, $22^{\circ} 0^{\prime} 42.77 " \mathrm{E}, 05$. 06. 2005; 56: Kuklica, SW, 499, 89, 16, 42 ${ }^{\circ} 5^{\prime} 10.00^{\prime \prime} \mathrm{N}, 22^{\circ} 0^{\prime}$ 45.00" E, 05. 06. 2005; 57: Ljoljak, S, 461, 94, 5, $42^{\circ}$ 5' 5.89" N, 210 57' 48.12" E, 04. 06. 2005; 58: Ljoljak, S, 467, 99, 4, 42 ${ }^{\circ} 5^{\prime} 7.26^{\prime \prime} \mathrm{N}, 2^{\circ} 57^{\prime} 46.64^{\prime \prime} \mathrm{E}$, 04. 06. 2004; 59: Konju, NE, 455, 98, 4, $42^{\circ} 5^{\prime}$ 5.90" N, 21 57' 50.79" E, 04. 06. 2004; 60: Konju, $\mathrm{S}, 470,98,6,42^{\circ} 5^{\prime} 8.15^{\prime \prime} \mathrm{N}, 21^{\circ} 57^{\prime} 44.43^{\prime \prime} \mathrm{E}, 07$. 06. 2004; 61: Konju, S, 464, 88, 3, 42 ${ }^{\circ} 5^{\prime} 10.22^{\prime \prime} \mathrm{N}$, $21^{\circ}$ 57' 36.31" E, 07. 06. 2004; 62: Pendać, SE, 592, $79,4,42^{\circ} 6^{\prime} 50.90^{\prime \prime} \mathrm{N}, 22^{\circ} 0^{\prime} 58.88$ " E, 05. 06. 2004; 63: Trnovac, SE, 550, 98, 4, $42^{\circ} 7^{\prime} 19.26^{\prime \prime} \mathrm{N}, 22^{\circ}$ 4' 43.17" E, 02. 06. 2004; 64: Trnovac, S, 559, 99, 5, $42^{\circ} 7^{\prime}$ 17.91" N, 22 4' 40.99" E, 02. 06. 2004; 65: Trnovac, S, 550, 94, 8, 42 ${ }^{\circ} 7^{\prime} 16.97^{\prime \prime} \mathrm{N}, 2^{\circ} 4^{\prime}$ 41.36" E, 03. 06. 2004; 66: Trnovac, E, 503, 90, 7, $42^{\circ} 7^{\prime} 17.35^{\prime \prime} \mathrm{N}, 2^{\circ} 4^{\prime} 52.55^{\prime \prime} \mathrm{E}, 03.06 .2004 ; 67$ : Trnovac, NE, 512, 97, 9, 42 ${ }^{\circ} 7^{\prime} 18.35^{\prime \prime} \mathrm{N}, 2^{\circ} 4^{\prime}$ 
51.06" E, 03. 06. 2004; 68: Trnovac, E, 495, 100, 5, $42^{\circ} 7^{\prime} 16.45^{\prime \prime} \mathrm{N}, 22^{\circ} 4^{\prime} 53.52^{\prime \prime} \mathrm{E}, 25.05 .2004$; 69: Trnovac, NE, 513, 97, 14, 42 $7^{\circ} 17.75^{\prime \prime} \mathrm{N}, 22^{\circ}$ 4' 50.33" E, 25. 05. 2004; 70: Trnovac, S, 526, 93, $17,42^{\circ} 7^{\prime} 15.36^{\prime \prime} \mathrm{N}, 22^{\circ} 4^{\prime} 45.20^{\prime \prime} \mathrm{E}, 26.05 .2004$; 71: Trnovac, S, 521, 86, $12,42^{\circ} 7^{\prime} 15.88^{\prime \prime} \mathrm{N}, 22^{\circ} 4^{\prime}$ 46.62" E, 27. 05. 2004; 72: Trnovac, S, 540, 98, 7, $42^{\circ} 7^{\prime} 16.30^{\prime \prime} \mathrm{N}, 22^{\circ} 4^{\prime} 43.08^{\prime \prime} \mathrm{E}, 26.05 .2004$;
Заедници од Erysimo-Trifolietum на брдските пасишта во северо-источниот дел на Република Македонија

Брдските пасишта на територијата на Република Македонија се секундарни вегетациски формации, формирани со сукцесивна и долготрајна деградација или со потполно уништување на шуми, пред се од редот Quercetalia pubescentis, класа Querco-Fagetea, во низинскиот појас до 1200 (1400m). Денес тие завземаат околу 521.000 hа од територијата на Rепублика Македонија. Припаѓаaт кон сојузите Trifolion cherleri Мицевски 1971, Saturejo-Thymion Мицевски 1970 и Armerio-Potentillion Мицевски 1978 од редот Astragalo-Potentilletalia Мицевски 1971 и класата Festuco-Brometea Br. Bl. 1943.

Теренските истражувања во текот на 2004 и 2005 година, опфатија голем број на локалитети во околината на Кратово, каде во оптималниот вегетациски период (мај и јуни) направени се 72 вегетациски снимки, за да се регистрира вкупниот флористчки состав на истражуваната вегетација.

На истражуваното подрачје доминира умерено континентална, а во неколку делови и планинска клима, со топли и суви лета и ладни зими. Средна годишна температура е $11,4{ }^{\circ} \mathrm{C}$

Вегетациските истражувања се направени со класичниот европски метод (Braun Blanquet 1964; Westhoff \& Van der Maarel, 1973).

Вегетациските снимки (сопствени и од литература), внесени се во базата со податоци Turboveg (Hennekens, 2001). Комбинираната проценка за бројност и покровност трансформирана е по Van der Maarel (1979). За таа цел користени се различни мултиваријантни анализи од компјутерските програми PC-ORD 4 (Mc Cune \& Mefford 1999), JUICE 6.4 (Tichý, 2006) и STATISTICA 7.0 (Stat Soft, Inc., www.statsoft.com).

По сеопфатните анализи и по споделувањето со претходно опишаните асоцијации на територијата на Република Македонија и соседните подрачја, дојдовме до заклучок дека на истражуваното подрачје се развиваат следните растителни заедници.

Ass. Erysimo-Trifolietum Мицевски 1977 (сојуз Trifolion cherleri, ред Astragalo-Potentilletalia, класа Festuco-Brometea).

Во асоцијацијата се издиференцирани две нови субасоцијации - scleranthetosum subass. nova и brachypodietosum subass. nova.

Subass. brachypodietosum subass. nova - e peгистрирана во близина на селото Трновац. Диференцијални видови на оваа субасоцијација се следните: Minuartia hamata, Brachypodium distachyon, Echinaria capitata, Ziziphora capitata, Linum corymbulosum, Coronilla scorpioides, Buffonia tenuifolia и Dianthus pallens.

Subass. scleranthetosum subass. nova - е регистрирана на повеќе локалитети во околината на Кратово. Диференцијални видови на субасоцијацијата scleranthetosum по кои се одвојува од субасоцијацијата brachypodietosum ce Logfia arvensis, Scleranthus perennis subsp. dichotomus, Sedum hispanicum, Verbascum lesnovoensis, Trifolium retusum, Valerianella turgida и Elymus hispidus subsp. hispidus. 
Table 1: Analytical table of ass. Erysimo diffusi-Trifolietum angustifolii Micevski 1977.

Tabela 1: Analitična tabela asociacije Erysimo diffusi-Trifolietum angustifolii Micevski 1977.

\begin{tabular}{|c|c|c|c|c|c|c|c|c|c|c|c|c|c|c|c|c|c|c|c|c|c|c|c|c|c|c|c|c|}
\hline Number of relevé & $\begin{array}{l}0 \\
1 \\
\end{array}$ & $\begin{array}{l}0 \\
2 \\
\end{array}$ & $\begin{array}{l}0 \\
3 \\
\end{array}$ & $\begin{array}{l}0 \\
4 \\
\end{array}$ & $\begin{array}{l}0 \\
5 \\
\end{array}$ & $\begin{array}{l}0 \\
6 \\
\end{array}$ & $\begin{array}{l}0 \\
7 \\
\end{array}$ & $\begin{array}{l}0 \\
8 \\
\end{array}$ & $\begin{array}{l}0 \\
9 \\
\end{array}$ & $\begin{array}{l}1 \\
0 \\
\end{array}$ & \begin{tabular}{|l}
1 \\
1 \\
\end{tabular} & & $\begin{array}{l}1 \\
3 \\
\end{array}$ & $\begin{array}{l}1 \\
4\end{array}$ & $\begin{array}{l}1 \\
5\end{array}$ & $\begin{array}{l}1 \\
6\end{array}$ & $\begin{array}{l}1 \\
7 \\
\end{array}$ & $\begin{array}{l}1 \\
8 \\
\end{array}$ & $\begin{array}{l}1 \\
9 \\
\end{array}$ & $\begin{array}{l}2 \\
0\end{array}$ & & $\begin{array}{l}2 \\
2 \\
\end{array}$ & $\begin{array}{l}2 \\
3 \\
\end{array}$ & $\begin{array}{l}2 \\
4 \\
\end{array}$ & $\begin{array}{l}2 \\
5 \\
\end{array}$ & $\begin{array}{l}2 \\
6 \\
\end{array}$ & & $\begin{array}{l}2 \\
8 \\
\end{array}$ \\
\hline \multicolumn{29}{|l|}{ Erysimo-Trifolietum } \\
\hline Erysimum diffusum & + & + & + & + & . & . & + & + & + & . & + & & + & + & + & + & + & & + & + & . & + & + & 1 & 1 & + & & + \\
\hline Trifolium sylvaticum & + & . & . & 1 & $\cdot$ & 2 & 2 & 1 & 1 & 1 & 1 & 1 & 1 & 1 & 2 & 2 & 3 & 1 & 1 & 1 & 1 & & + & 1 & 1 & + & & . \\
\hline Trifolium angustifolium & . & . & . & . & . & . & + & . & . & + & . & . & . & . & & + & + & + & + & + & + & . & . & . & + & 2 & + & + \\
\hline Trifolium leucanthum & . & . & . & 1 & . & 1 & + & + & + & + & . & + & 1 & + & . & . & . & . & . & . & . & . & . & . & + & + & 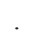 & 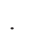 \\
\hline Vulpia myuros & . & . & . & . & . & + & . & . & . & . & 1 & 1 & + & 2 & 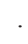 & 1 & + & . & . & 1 & . & . & . & . & . & . & $\cdot$ & . \\
\hline Trifolium echinatum & 1 & . & . & . & . & . & . & . & . & . & . & . & . & + & + & . & . & . & . & . & . & . & . & . & . & · & . & . \\
\hline Trifolium striatum subsp. striatum & $\cdot$ & . & . & . & . & . & . & . & . & . & . & . & + & . & . & . & . & . & . & . & . & . & . & . & . & . & . & + \\
\hline Trifolium physodes & $\cdot$ & . & . & . & . & . & . & . & . & . & . & . & . & . & . & . & . & . & . & . & . & $\cdot$ & $\cdot$ & . & . & $\cdot$ & . & . \\
\hline Ventenata dubia & . & . & . & . & . & . & . & + & . & . & . & . & . & . & . & . & . & . & . & . & . & . & . & . & . & . & . & \\
\hline \multicolumn{29}{|l|}{ scleranthetosum subass. nova } \\
\hline Logfia arvensis & 2 & 3 & 2 & 3 & 3 & 1 & 1 & 1 & 2 & 2 & 2 & 2 & + & 1 & 3 & 1 & 1 & 3 & 2 & 2 & 2 & . & . & . & . & . & + & + \\
\hline Scleranthus perennis subsp. dichotomus & . & . & 3 & 1 & . & 1 & . & 1 & 1 & 3 & 2 & + & . & + & 1 & . & + & . & + & . & + & . & . & . & . & . & . & . \\
\hline Sedum hispanicum & 1 & + & . & 1 & 2 & 1 & . & + & 2 & 2 & 2 & 1 & 1 & . & . & . & & + & . & . & . & . & . & 1 & + & . & . & . \\
\hline Verbascum lesnovoensis & 1 & + & + & + & . & . & . & . & + & . & + & + & + & . & + & + & . & . & . & + & + & . & . & . & . & . & . & . \\
\hline Trifolium retusum & . & . & . & + & . & . & . & . & + & + & . & + & + & . & + & . & . & . & . & . & . & . & + & . & . & . & + & 1 \\
\hline Valerianella turgida & . & . & . & 2 & . & 2 & 1 & 3 & . & . & + & . & . & . & . & . & . & + & + & + & + & + & . & . & . & . & . & . \\
\hline \multirow{2}{*}{\multicolumn{29}{|c|}{ brachypodietosum subass. nova }} \\
\hline & & & & & & & & & & & & & & & & & & & & & & & & & & & & \\
\hline Minuartia hamata & . & . & . & . & $\cdot$ & . & . & . & . & . & . & . & . & . & . & . & . & . & . & . & . & + & . & . & . & . & . & . \\
\hline Brachypodium distachyon & $\cdot$ & . & . & . & . & . & . & . & . & · & . & . & · & · & . & . & . & . & . & · & · & $\cdot$ & $\cdot$ & . & $\cdot$ & . & . & $\cdot$ \\
\hline Echinaria capitata & . & . & . & . & . & . & . & . & . & . & . & . & . & . & · & . & . & . & . & . & . & . & . & . & . & . & . & . \\
\hline Ziziphora capitata & $\cdot$ & . & . & . & . & . & . & . & . & . & . & . & . & . & · & . & . & . & . & . & . & . & . & . & . & . & $\cdot$ & . \\
\hline Linum corymbulosum & . & . & . & . & . & . & . & . & . & . & . & . & . & . & . & . & · & . & . & . & . & . & . & . & . & . & . & . \\
\hline Coronilla scorpioides & $\cdot$ & . & . & . & . & . & . & . & . & . & . & . & . & . & . & . & . & . & . & . & . & . & . & . & . & $\cdot$ & . & . \\
\hline Buffonia tenuifolia & . & . & . & . & . & . & . & . & . & . & . & . & · & · & $\cdot$ & . & · & . & . & . & . & . & . & . & . & . & . & . \\
\hline Dianthus pallens & $\cdot$ & . & . & . & . & . & . & . & . & . & . & . & . & . & . & . & . & . & . & . & . & . & . & . & . & . & $\cdot$ & ${ }^{\circ}$ \\
\hline \multicolumn{29}{|l|}{ Trifolion cherleri } \\
\hline Taeniatherum caput-medusae & 1 & 1 & 2 & . & 1 & 1 & 1 & 2 & + & 1 & 1 & 1 & 1 & 1 & 2 & 3 & 2 & 2 & 1 & 1 & 2 & 1 & . & + & + & 1 & 1 & 1 \\
\hline Petrorhagia prolifera & + & + & + & + & . & . & 1 & 1 & + & 1 & 1 & 1 & 1 & + & + & 1 & 1 & . & + & + & 1 & + & + & + & + & + & & + \\
\hline Galium macedonicum & $\cdot$ & + & + & . & . & + & . & . & . & . & . & . & . & . & . & . & . & . & . & 1 & + & + & . & 1 & + & . & + & . \\
\hline Vulpia ciliata & . & . & . & . & . & 1 & . & 2 & + & + & 1 & 2 & 2 & . & + & . & . & . & . & . & . & . & . & . & . & . & + & + \\
\hline Silene frivaldskyana & + & + & + & . & . & . & . & . & . & . & . & . & . & . & . & + & + & . & . & . & . & . & . & . & . & . & . & . \\
\hline Allium guttatum subsp. sardoum & $\cdot$ & . & . & . & . & . & . & . & . & . & . & . & . & . & + & . & . & . & . & . & . & . & . & . & . & . & . & . \\
\hline Aphanes arvensis & . & . & . & . & . & + & . & . & . & + & . & . & . & 1 & . & . & . & . & . & . & • & . & 1 & . & . & . & . & . \\
\hline \multicolumn{29}{|l|}{ Astragalo-Potentilletalia } \\
\hline Astragalus onobrychis var. chlorocarpus f. chlorocarpus & + & 2 & 1 & 2 & 2 & 2 & 2 & 2 & 2 & 2 & 1 & 2 & 2 & 2 & 2 & 2 & 2 & 2 & 1 & 1 & 1 & + & 1 & 1 & + & 1 & + & 1 \\
\hline Bromus squarrosus & 1 & 2 & 1 & 2 & 2 & 2 & 1 & 2 & 3 & 2 & 2 & 2 & + & 3 & 1 & 2 & 2 & 2 & 1 & 2 & 2 & + & + & 1 & 1 & + & 2 & 2 \\
\hline Centaurea grisebachii & + & + & . & 2 & 1 & 1 & 1 & 1 & 1 & 1 & 1 & 1 & + & + & + & 1 & + & + & + & + & 1 & 1 & + & + & + & + & . & . \\
\hline Potentilla laciniosa & . & . & + & 1 & 2 & 1 & 1 & . & + & 1 & 1 & + & 1 & 1 & + & 2 & 1 & 3 & 2 & 1 & 2 & + & + & 1 & + & + & . & . \\
\hline Thymus pseudo-atticus var. vardarensis & 2 & 2 & 2 & 3 & 3 & 2 & 1 & 2 & 1 & 2 & 2 & 2 & 3 & 3 & + & 2 & 2 & 1 & 1 & 1 & 1 & . & . & 2 & 2 & + & + & + \\
\hline Dasypyrum villosum & 1 & 2 & 1 & 1 & 2 & 1 & + & 1 & 1 & 1 & + & + & + & 1 & + & + & . & . & . & . & . & + & . & + & 1 & 1 & 1 & . \\
\hline Medicago rigidula & 3 & 2 & 3 & + & + & 1 & 1 & 2 & 1 & 1 & + & 1 & 1 & 1 & 1 & + & + & 1 & + & + & 1 & + & + & + & 1 & + & + & + \\
\hline Aegilops neglecta & 2 & + & + & 1 & 1 & + & + & + & + & + & 1 & + & 1 & + & - & . & . & . & . & . & & + & + & . & + & + & 1 & 1 \\
\hline Xeranthemum аппиит & + & 1 & 1 & 1 & 1 & + & + & 1 & + & + & 1 & + & + & + & + & + & 1 & 1 & 2 & 1 & 1 & + & + & + & + & + & + & + \\
\hline Ornithogalum comosum & . & . & + & + & + & 1 & 1 & 1 & + & & . & + & 1 & | & + & + & 1 & 1 & 1 & 1 & t & $\cdot$ & + & 1 & 1 & 1 & + & + \\
\hline Sedum sartorianum & . & . & 1 & 1 & 1 & . & 1 & 1 & + & + & + & + & + & 1 & & 1 & & . & . & & & + & 1 & + & + & . & . & . \\
\hline Hypericum rumeliacum var. rumeliacum & + & + & + & 1 & . & 1 & 1 & + & . & + & + & + & & 1 & & & + & . & . & . & & 1 & + & + & + & + & $\cdot$ & . \\
\hline Petrorhagia illyrica subsp. haynaldiana & + & + & + & + & + & + & + & + & . & . & & + & & & & & & . & . & . & & + & + & $\cdot$ & . & & + & + \\
\hline Dianthus gracilis subsp. gracilis & . & + & + & & . & + & + & . & . & $\cdot$ & & & & . & $T$ & & & . & · & • & & + & + & 1 & 1 & & & + \\
\hline Galium tenuissimum & . & & . & 2 & 1 & 1 & 1 & 1 & . & 1 & + & + & & 2 & 1 & 1 & 2 & 2 & 3 & 1 & & & 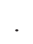 & . & . & . & + & 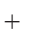 \\
\hline
\end{tabular}


$\begin{array}{lllllllllllllllllllllllllllllll}+ & 1 & 1 & 1 & 1 & 1 & 1 & 1 & 1 & 1 & 1 & 1 & 1 & 1 & + & 1 & + & + & + & 1 & 1 & 1 & 1 & 1 & + & 1 & + & . & \cdot & . & + \\ +\end{array}$ $1+11+1111+1++++++++++1+111+2+222122$ .+++++ . . . . + . . . . . . ..++++++ . . . . . . . $+.1+. .5 .+.++.1$. . . . . . . . . . . . . . . ..++ . . . . . . . . . . . . . . . . . . . . . . . . . . . . . . 1 . $+$

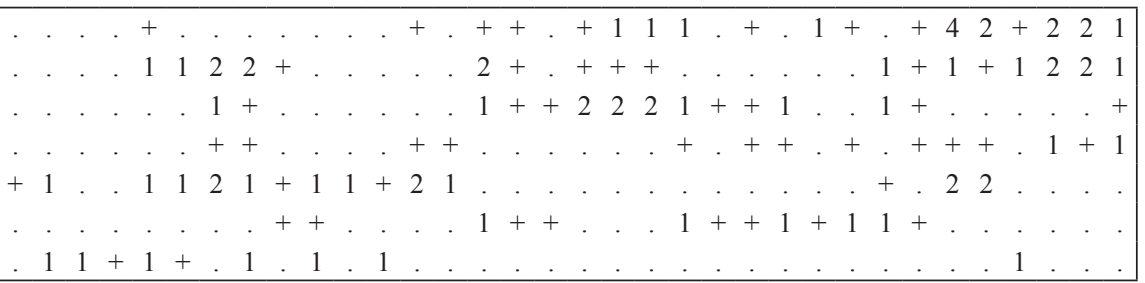

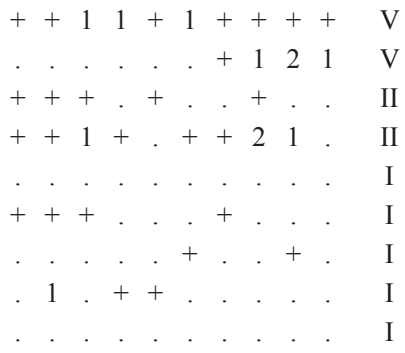




\section{Number of relevé}

Crepis sancta

Minuartia hirsuta subsp. falcata

Torilis leptophylla

Scabiosa triniifolia

Petrorhagia illyrica subsp. illyrica

Acinos hungaricus

Anthemis ruthenica

Viola kitaibeliana

Onobrychis alba subsp. calcarea var. echinata

Crepis foetida subsp. rhoeadifolia

Crucianella graeca

Sideritis montana

Leontodon crispus subsp. crispus

Rumex acetosella var. multifidus

Festuca thracica subsp. violaceo-sordida

Bupleurum apiculatum

Thymus tosevii subsp. tosevii var. tosevii

Allium meteoricum

Petrorhagia saxifraga

Linaria simplex

Thymelaea passerina f. passerina

Echinops microcephalus

Tragopogon balcanicus

Potentilla argentea

Plantago subulata

Onobrychis alba subsp. calcarea

Scabiosa argentea subsp. ucranica

Allium stamineum

Medicago prostrata subsp. pseudorupestris var. pseudorupestris f. pseudorupestris

Euphorbia seguieriana subsp. niciciana

Onobrychis alba subsp. calcarea var. striatula

\section{Festuco-Brometea}

Eryngium campestre

Trifolium scabrum f. scabrum

Poa bulbosa

Herniaria incana var. incana

Dichanthium ischaemum

Holosteum umbellatum

Trifolium incarnatum subsp. molinerii

Convolvulus cantabrica

Trigonella monspeliaca

Asperula cynanchica

Melica ciliata

Teucrium polium

Bombycilaena erecta

Chondrilla juncea

Euphorbia cyparissias

Koeleria splendens

Carthamus lanatus

Chrysopogon gryllus

Achillea setacea

Sanguisorba minor subsp. muricata

Phleum phleoides \begin{tabular}{llllllllll|l|lllllllllllllllll}
0 & 0 & 0 & 0 & 0 & 0 & 0 & 0 & 0 & 1 & 1 & 1 & 1 & 1 & 1 & 1 & 1 & 1 & 1 & 2 & 2 & 2 & 2 & 2 & 2 & 2 & 2 & 2
\end{tabular} \begin{tabular}{llllllllll|l|lllllllllllllllll}
1 & 2 & 3 & 4 & 5 & 6 & 7 & 8 & 9 & 0 & 1 & 2 & 3 & 4 & 5 & 6 & 7 & 8 & 9 & 0 & 1 & 2 & 3 & 4 & 5 & 6 & 7 & 8
\end{tabular}

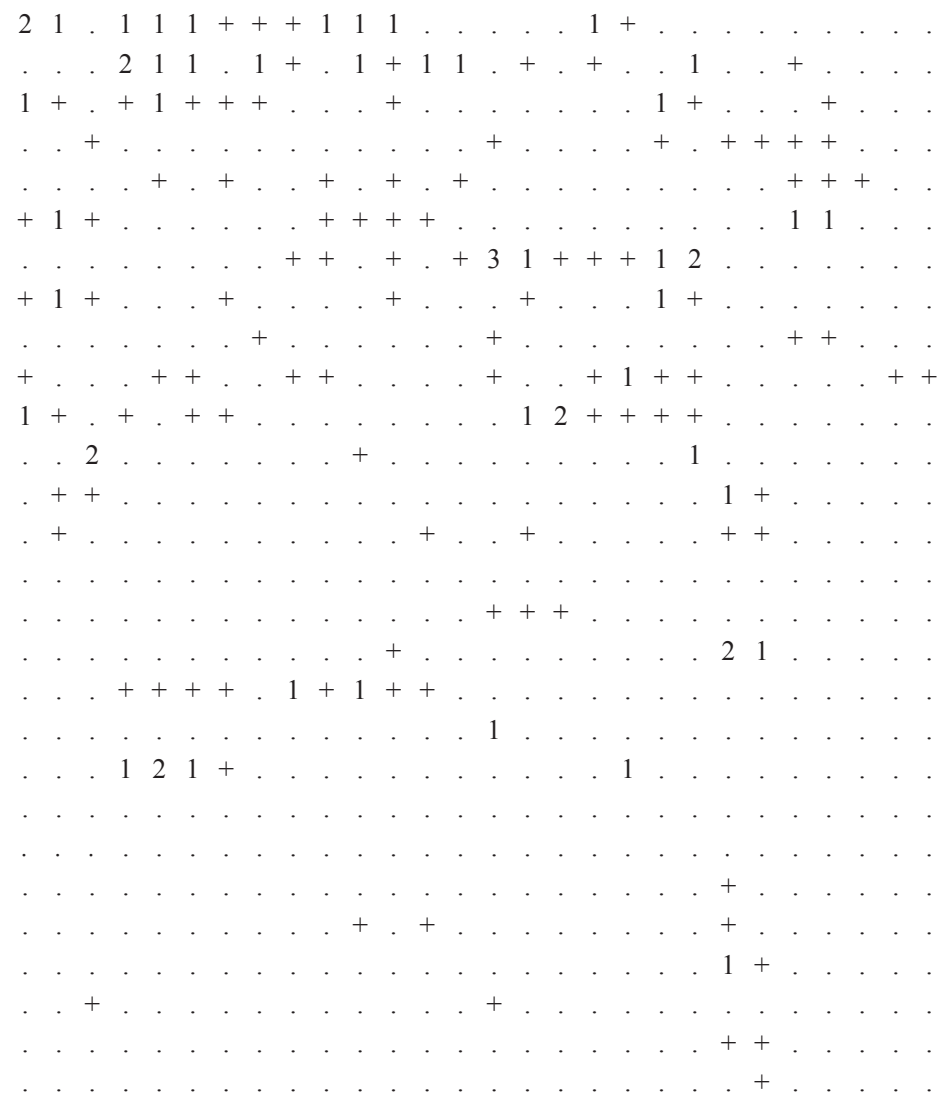

112

$1+$

$1 .+21111+111+11+111+111++1++$

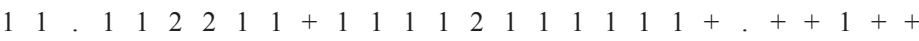

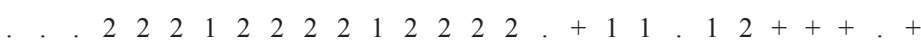

$++.++++++1+1++.+1+++.+$. . . . ++

$221+21 .+.1 .1 .11+. .+++12+++++$

....++++++++++++++++++++ . . . .

.. . ++ ...+++++++ . . . . . . . . $+11++$

$++1211111+1+.+++11+1+1 . .+. .$.

$+++++11+11+++++++1+.++++. .$. .

....+++++++++ . $+.+++.+2+$. . . ++

$++++++++. .+. . .++.+1++1+11 .$.

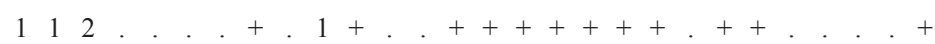

. . . . . . . . . . . . . . . . . . . . ++ . . . . .

. . . +++ . ...+++++ . +++ . . . +++++

.. . + . . . . . . $+++.++. .+.1+\ldots .+++$

. . $2+111$. . . . . . . . . . . . . 2121.

.. . $++1++.+.++++.1++1$. . . . . . + .

. ++++++ . ++ . . . $+2++++$. . . $1+2$

.. . +.211 . 2 . . . . + . . . . . . . . . $++.1+$

.. . + . . . . $1++11$. $1+. . .611$. . . . .

... ...+ . . . . . . . . . . . +.1111 
$\begin{array}{llllllllllllllllllllllllllllllllll}2 & 3 & 3 & 3 & 3 & 3 & 3 & 3 & 3 & 3 & 3 & 4 & 4 & 4 & 4 & 4 & 4 & 4 & 4 & 4 & 4 & 5 & 5 & 5 & 5 & 5 & 5 & 5 & 5 & 5 & 5 & 6 & 6 & 6\end{array}$

$\begin{array}{lllllllllllllllllllllllllllllllllll}9 & 0 & 1 & 2 & 3 & 4 & 5 & 6 & 7 & 8 & 9 & 0 & 1 & 2 & 3 & 4 & 5 & 6 & 7 & 8 & 9 & 0 & 1 & 2 & 3 & 4 & 5 & 6 & 7 & 8 & 9 & 0 & 1 & 2\end{array}$

\begin{tabular}{lll|l|llllll}
6 & 6 & 6 & 6 & 6 & 6 & 6 & 7 & 7 & 7 \\
3 & 4 & 5 & 6 & 7 & 8 & 9 & 0 & 1 & 2
\end{tabular}

... +........ . . . + . +. . . $1+++++.+. .1+1$

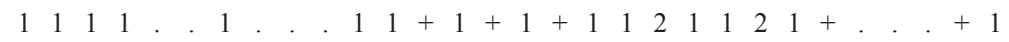

\begin{tabular}{llll|llllll}
3 & 4 & 5 & 6 & 7 & 8 & 9 & 0 & 1 & 2
\end{tabular}

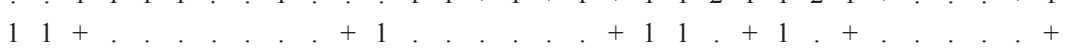

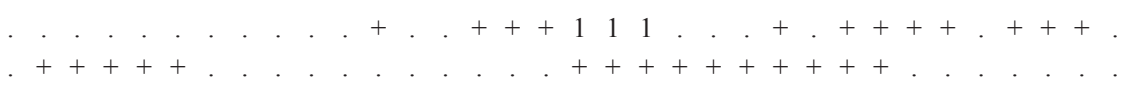
$+++222++++.1111$

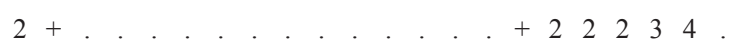

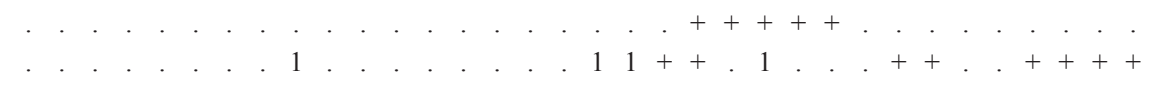

+. . . . . . . . . . . . . +++ . . . . . . . . . . . ++ + + . +

. . . . . . . . + . . . . . . . . . . . . . . . . . . . . . . .

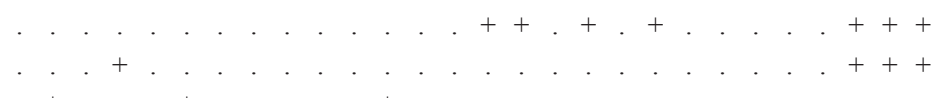

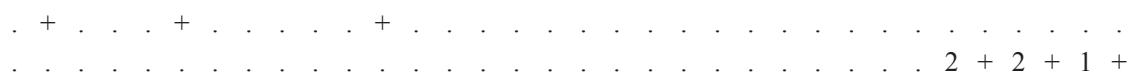
$\begin{array}{llllllllllll}1 & 1 & 1 & 1 & 1 & 1 & 1 & 2 & 2 & 1 & \text { III }\end{array}$ $\cdot \cdot \cdot \cdot \cdot \cdot \cdot \cdot \cdot \cdot \cdot \cdot \frac{1 I I}{6}$ $++++++1+1$ III . ..+++ . . . II ....++++ II $+++1+$. 12 1

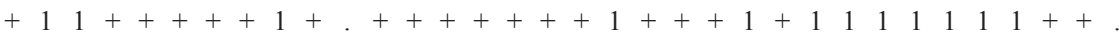

$\begin{array}{llllllllllllllllllll}1 & 1 & 1 & 1 & 1 & 1 & 1 & 1 & 1 & 1 & 2 & 1 & 1 & 1 & . & 1 & + & + & +++++++ \\ + & ++ & + & 1 & 1 & 2 & 2 & 1 & 1 & 1\end{array}$

+1 . . $232321133+2111121+++++++$. . 2333222 $++++\begin{array}{lllllllllllll} & 1 & 1 & 1 & + & 1 & 1 & 1 & 1 & . & + & + & +\end{array}$ +. . . . . . . . . . . $++++++++++++1.1+++1+$ . . . . ..+++++++ ..+ . . . ++++++++ . ...+++ $+11+1++++++3+++. . .2 . .+.++\ldots++. .++$..+ . $+1++++$. . . . $1+$. . . $++2+++1.1+11 .++$. .. . . . . . . . . . . . $++++.++.++.++.++21+2$ +. . . . . . . . . . . . . +++ . . . ++++++++++ . ++ . . . . . . . . . . . $+11++++22+++1111 \%$. +++ + . . . . . . . . . . . . . . . 1 . . 1 . $1+11+2+$. +++ $1++++111+1.1++++1++11111111+$

++++++ . . . . . ..+++++++ . . . . ....+++++++ .+++++ . . . . . + . . . ++++ . . . . . . ++ . . . . . . . .

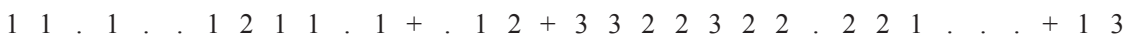
. ++ . . ..++++++ . . . . . $+.+.++.++1.1+$. $1 .+$. . . . . . . . . . $2 .+. .+. .+1++. .+$. $+11+++++11+.11$. . . . . . . . . . . . . . . . . ++++++ . . . . . . . . . . . . +++++ . . . . ..++

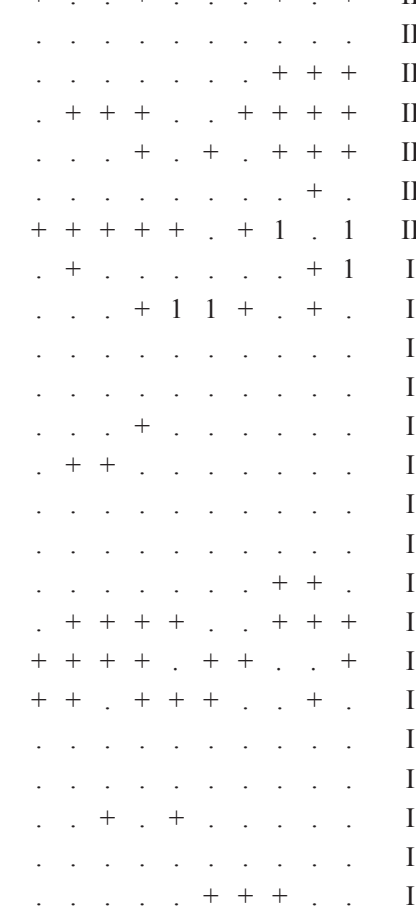

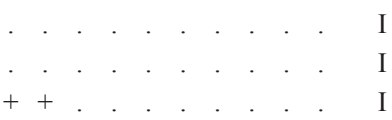

$1+++++111+\mathrm{V}$ $+++.++11 \mathrm{~V}$ $1++21+11 \mathrm{~V}$ . + +. $+.1+++$ IV $\begin{array}{lllllllllll}2 & 3 & 1 & 3 & 3 & 2 & 2 & 2 & 2 & 3 & \mathrm{~V}\end{array}$ . . . . . +++ IV ..+++++++ IV . . . . . +++ IV . . ++ . ++ . III ...+++++ III . . . . . . . ++ . III $++1+++++++$ III $\begin{array}{lllllllllll}2 & 2 & 1 & 2 & 2 & 1 & 1 & 1 & 1 & 1 & \text { III }\end{array}$ + . . . . . . . III $+++1+.+++$ III

. . . . . . . . . III

. . . . . . +++ III . . . . . . ++ . III +++ . . . . . . . II $\begin{array}{llllllllll}1 & 1 & 1 & 1 & 1 & 1 & + & 1 & 1 & \text { II }\end{array}$ 


\section{Number of relevé}

Echinops sphaerocephalus subsp. sphaerocephalus Hieracium praealtum subsp. bauhinii

Koeleria nitidula

Festuca valesiaca

Neatostema apulum

Alyssum alyssoides

Allium sphaerocephalon subsp. arvense

Carlina vulgaris

Medicago falcata subsp. tenderiensis

Phleum phleoides var. blepharodes

Astragalus hamosus

Scilla autumnalis

Linum austriacum

Filago vulgaris

Galium verum

Teucrium chamaedrys

Silene otites

Sedum annuum

Minuartia viscosa f. viscosa

Valerianella eriocarpa

Herniaria glabra

Lens nigricans f. ciriferum

Bupleurum affine var. quadridentatum

Linaria genistifolia

Ononis spinosa subsp. spinosa

Thesium arvense

Inula oculus-christi

Vinca herbacea

Arabidopsis thaliana

Achillea pannonica

Phlomis herba-venti subsp. pungens

Allium moschatum

Helianthemetea guttati; Helianthemetalia guttati

Medicago minima var. minima

Trifolium campestre var. campestre

Trifolium arvense var. arvense

Helianthemum salicifolium

Arenaria serpyllifolia var. viscida

Silene conica subsp. conica

Veronica verna

Myosotis stricta

Psilurus incurvus

Vicia lathyroides

Crupina vulgaris

Erophila verna

Sedum rubens

Hypochoeris glabra

Sedum caespitosum

Helianthemum ledifolium

\section{Others}

Achillea coarctata

Erodium cicutarium

Cruciata pedemontana

Carduus thoermeri $\begin{array}{lllllllllllllllllllllllllllll}0 & 0 & 0 & 0 & 0 & 0 & 0 & 0 & 0 & 1 & 1 & 1 & 1 & 1 & 1 & 1 & 1 & 1 & 1 & 2 & 2 & 2 & 2 & 2 & 2 & 2 & 2 & 2\end{array}$ \begin{tabular}{llllllllll|llllllllllllllllll}
1 & 2 & 3 & 4 & 5 & 6 & 7 & 8 & 9 & 0 & 1 & 2 & 3 & 4 & 5 & 6 & 7 & 8 & 9 & 0 & 1 & 2 & 3 & 4 & 5 & 6 & 7 & 8
\end{tabular}

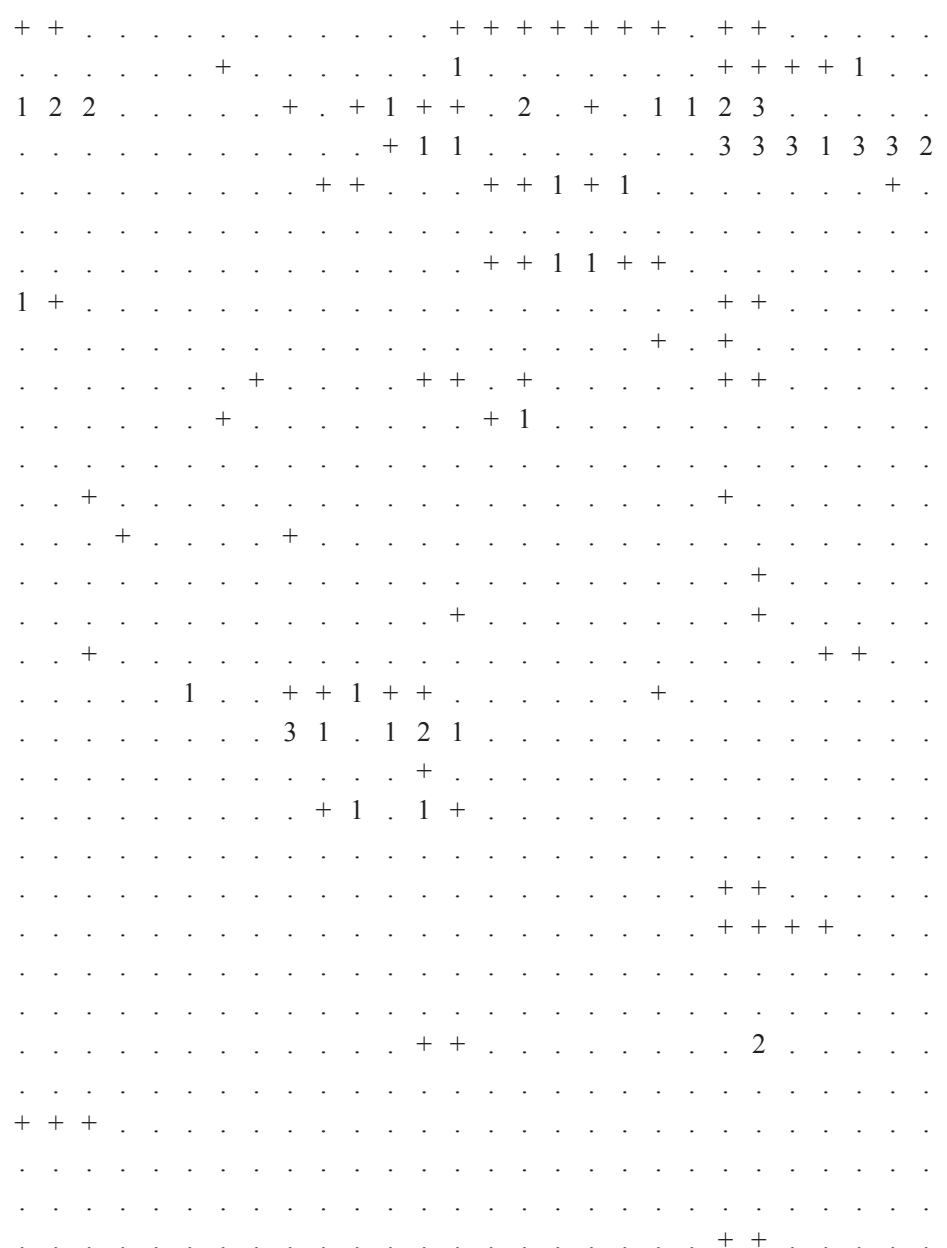

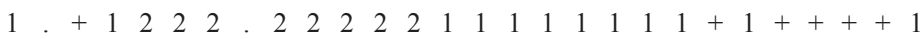
$2211+111$. . . + + + + $211+11111112111$

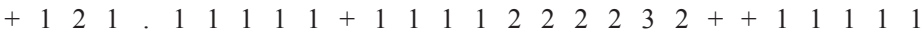

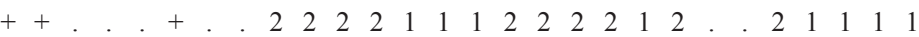

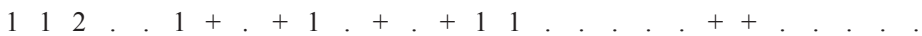

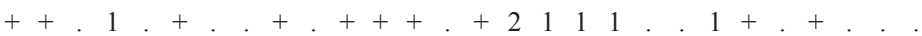

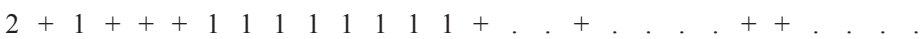
$++.1+111+11++++++1+++++. . .$. $+.22+2+2+22+212$. $211+. . . .$. $+2+$. . . . . . . . . . . . . . $1+. .2+1$ $+.1+$. . . . . . . . . +1 . . 11 . . $1+$. .. . . . . . ++++++ . . . . . . . . . . . .

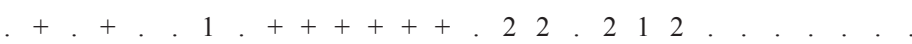
.. . . . . . ++++ . ++1 . ++ . . . . . ++

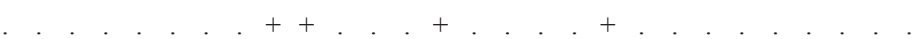
. 1 1 . . . . . . . . . . . . . . . . . . . . . . . .

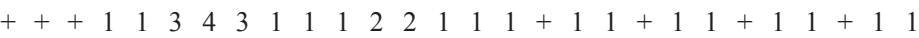
$1+.1+.++1+1+1111111+1+.+. . .$. $++.1+21+. .+++. .+.++. .+.++++$ $+.1++.++$. . . . . ........+++++++ 


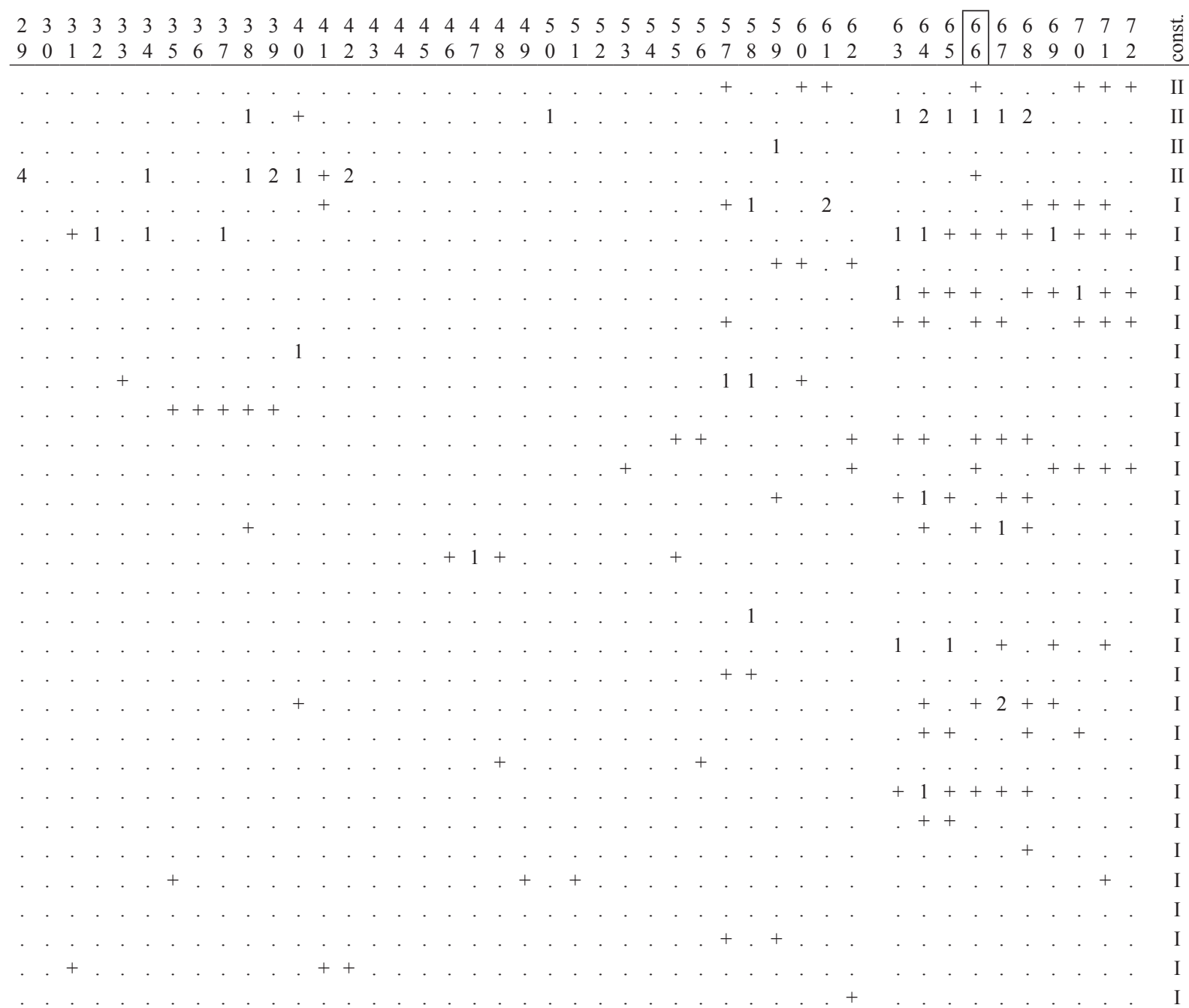

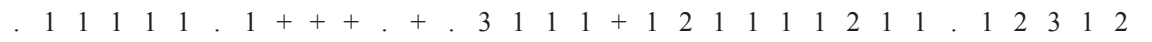

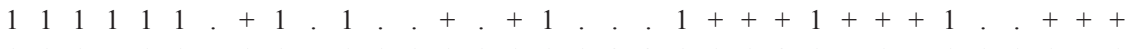

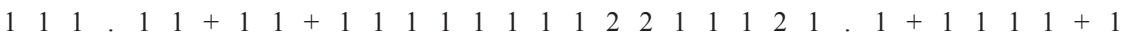
$11.11+.221 . .1+. .2+. .+++11+11+22111$

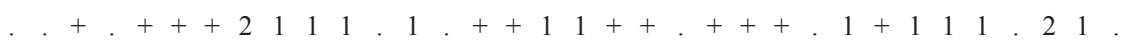
...+++ . . . . . $++1+\ldots+11+++1+111+++++3$

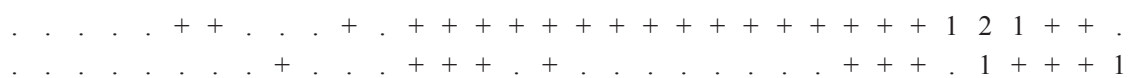

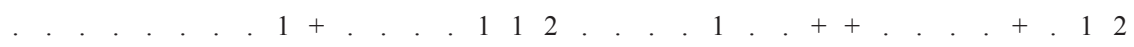
+. . . . . . . . . $+.+1+1.2 .+++++1++$.

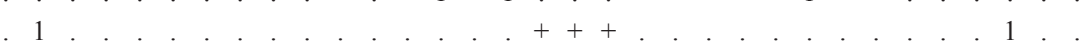
... . . . ++++++++ . . . . . . ++++++++ . $+$

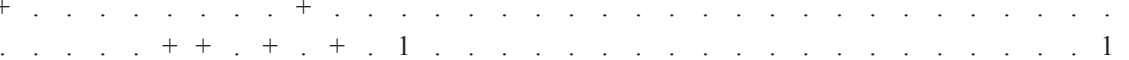
$+1111+11++++2+++1111++112121+211+2$ ... . . ++++++++ . . . . . $++++++++11+1++$ +++++ ..+++ $+++.++++1+. .1+.+.1++.+.+++. .+++++$ $\begin{array}{llllllllllll}2 & 2 & 2 & 2 & 2 & 1 & 2 & 2 & 3 & 3 & \mathrm{~V}\end{array}$

$+1+1211122 \mathrm{~V}$

$\begin{array}{lllllll}1 & 2 & 1 & 2 & 1 & 2 & \end{array}$ $1+2 \begin{array}{llllllll}1 & 1 & 1 & 2 & 1 & 2 & 1 & \text { IV }\end{array}$ ...++ ..+ . III $+. . .5 .+$. .. III . . $+. .1+++$ III . . . . . $+.2 \mathrm{II}$ ......++ . II +++++++++ II . . . . . . . . II . . . . . . . . $\mathrm{I}$ $\cdot \cdot \cdot \cdot \cdot \cdot \cdot \cdot \cdot \cdot$ I . $2 . .++++\mathrm{V}$ . . . . . . $+++\mathrm{IV}$ $+2+++++++$. III

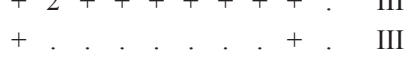




\section{Number of relevé}

Valerianella coronata

Nigella arvensis f. tuberculata

Trifolium hirtum

Stipa capillata

Plantago lanceolata

Tribulus terrestris var. terrestris

\section{Crepis setosa}

Taraxacum officinale

Tragopogon dubius

Paliurus spina-christi

Cerastium brachypetalum subsp. roeseri

Sherardia arvensis

Cynosurus echinatus

Polygonum aviculare

Conyza canadensis

Calepina irregularis

Centaurea solstitialis subsp. solstitialis

Eragrostis minor

Euphorbia helioscopia

Portulaca oleracea

Alyssum desertorum

Bromus tectorum

Setaria viridis

Anthemis austriaca

Orlaya grandiflora

Scleranthus annuus subsp. polycarpos

Vicia hirsuta

Carthamus dentatus

Tragus racemosus

Gagea arvensis

Ranunculus ficaria subsp. calthifolis

Digitalis lanata

Marrubium peregrinum

Heliotropium europeum

Hieracium hoppeanum subsp. troicum

Papaver rhoeas subsp. rhoeas

Convolvulus arvensis

Alyssum strigosum

Carduus acanthoides

Lactuca serriola

Lathyrus cicera

Arrhenatherum elatius

Picnomon acarna

Stachys plumosa

Buglossoides arvensis

Herniaria hirsuta f. hirsuta

Anthemis arvensis

Saxifraga tridactylites

Lathyrus nissolia var. nissolia

Geranium columbinum

Hypecoum pendulum

Myosotis arvensis

Cichorium intybus

Lotus corniculatus var. tenuis $\begin{array}{lllllllllllllllllllllllllllll}0 & 0 & 0 & 0 & 0 & 0 & 0 & 0 & 0 & 1 & 1 & 1 & 1 & 1 & 1 & 1 & 1 & 1 & 1 & 2 & 2 & 2 & 2 & 2 & 2 & 2 & 2 & 2\end{array}$ \begin{tabular}{llllllllll|l|lllllllllllllllll}
1 & 2 & 3 & 4 & 5 & 6 & 7 & 8 & 9 & 0 & 1 & 2 & 3 & 4 & 5 & 6 & 7 & 8 & 9 & 0 & 1 & 2 & 3 & 4 & 5 & 6 & 7 & 8
\end{tabular}

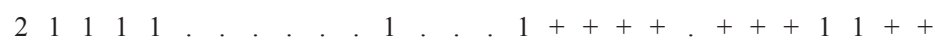

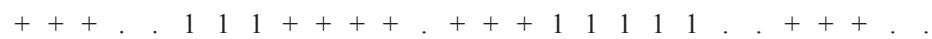

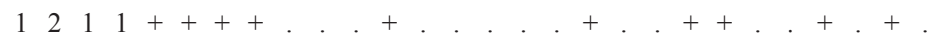

.. . . + . . . . . . . . $+1+. .2 .23 .++$

. . . . . ++ ..+++ . . . . . . . ...++++

. . ++ . . . +++++++++++++ . . . . . . .

$+. .++++1+.+.1 .++. .+++.+. .22$

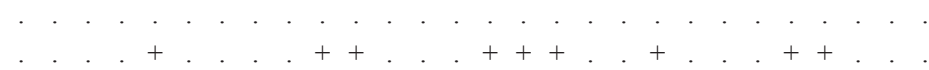

$++1 .++++.+\ldots+.+.+. .+.+\ldots . . .$.

.. . . . . . . . + . . . . . . . . 221811 .

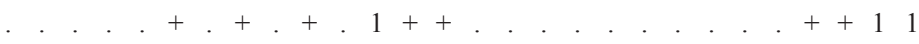

.. . . ++ . . . . ..++++.1 . . . ++++

.. . +++++ . . . + . . . +++++ . . +++ . .

++ . . . . . ...+++++++++ . . . . . . .

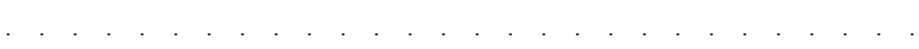

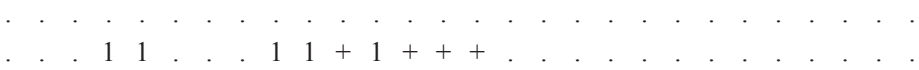

. . . . . . . . . . . . . . . . . . . . . . . . . .

. . . . . . . +++++++ . . . . . . . . . . . . .

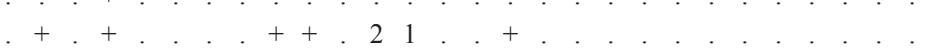

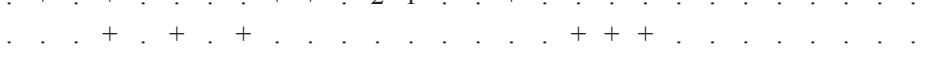

. . +++++ . . . . + . . . . . . . . . . . . . . . .

..++ . . . . . . + . . . . . . . . . . . . . . .

. . . . . . 2 . $2++2$. . . . . . . . . . .

+1 . . . . . . . . . . . . . . . . . . + + . . . + .

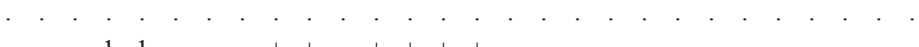
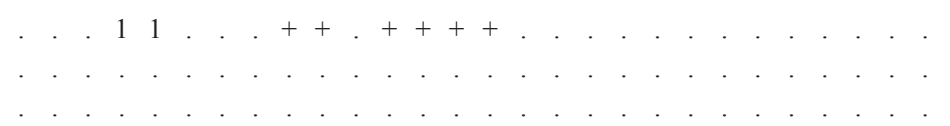

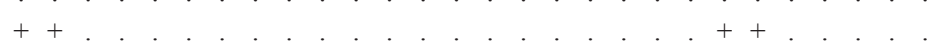

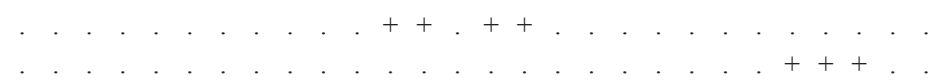

. . . . . . . . . . . . 1 . . . . . . . . . . . . . .

.. . . ++ . . . . . . $+11+$. . . . . . .

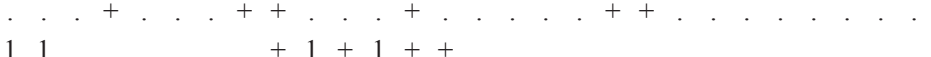

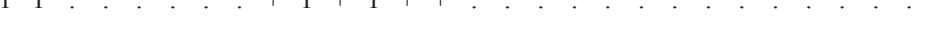

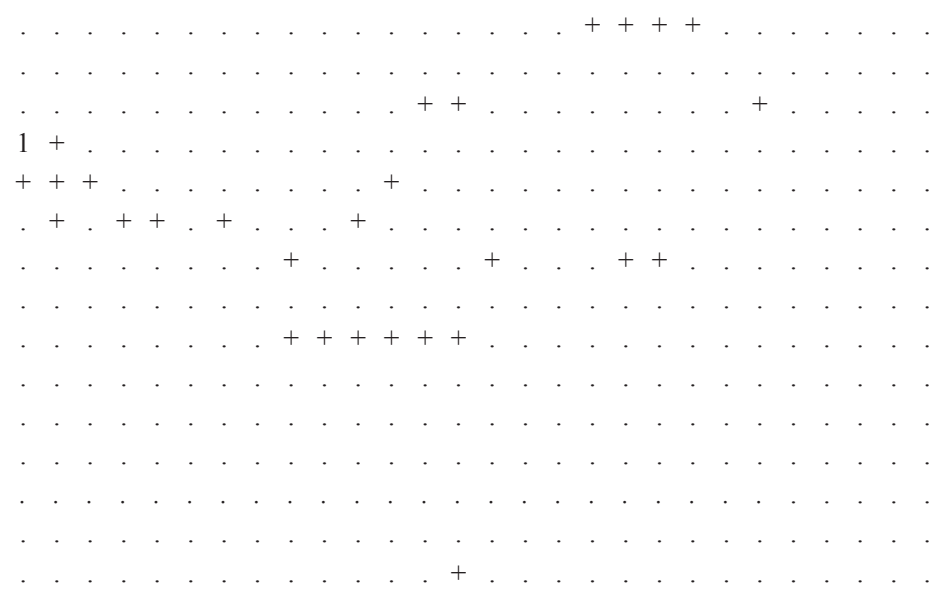




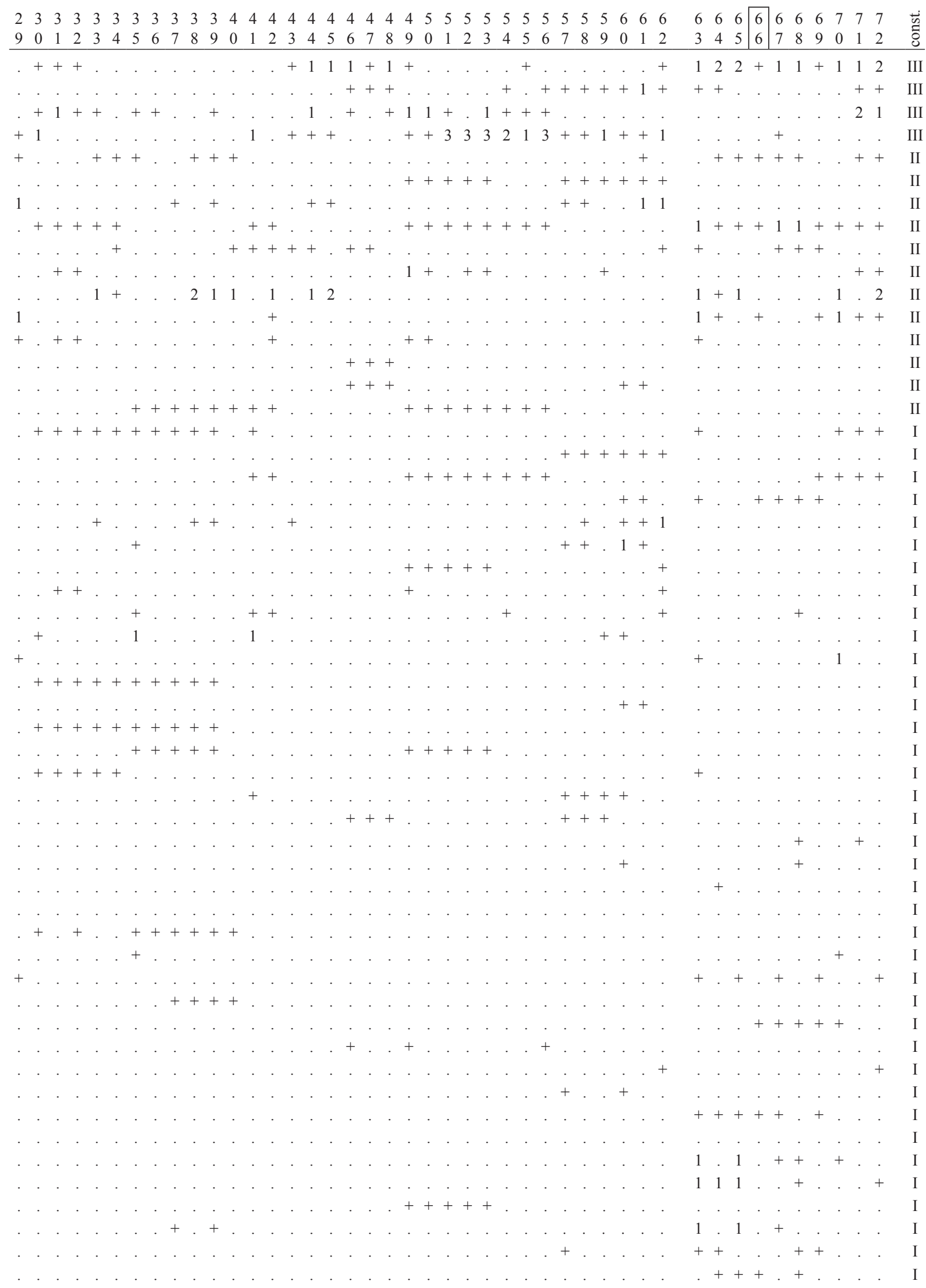


Number of relevé

$\begin{array}{lllllllllllllllllllllllllllll}0 & 0 & 0 & 0 & 0 & 0 & 0 & 0 & 0 & 1 & 1 & 1 & 1 & 1 & 1 & 1 & 1 & 1 & 1 & 2 & 2 & 2 & 2 & 2 & 2 & 2 & 2 & 2\end{array}$

\begin{tabular}{llllllllll|llllllllllllllllll}
1 & 2 & 3 & 4 & 5 & 6 & 7 & 8 & 9 & 0 & 1 & 2 & 3 & 4 & 5 & 6 & 7 & 8 & 9 & 0 & 1 & 2 & 3 & 4 & 5 & 6 & 7 & 8
\end{tabular}

Colchicum hungaricum

Medicago orbicularis

Lamium amplexicaule

Triticum baeoticum

Muscari racemosum

Geranium rotundifolium

Torilis arvensis subsp. arvensis

Trifolium nigrescens

Stachys germanica

Euphorbia taurinensis

Asperugo procumbens

Tordylium maximum

Anchusa officinalis

Polycnemum arvense

Delphinium balcanicum

Carex praecox

Carduus hamulosus

Fumaria thuretii

Crepis pulchra

Scabiosa sicula

Bromus hordeaceus subsp. hordeaceus

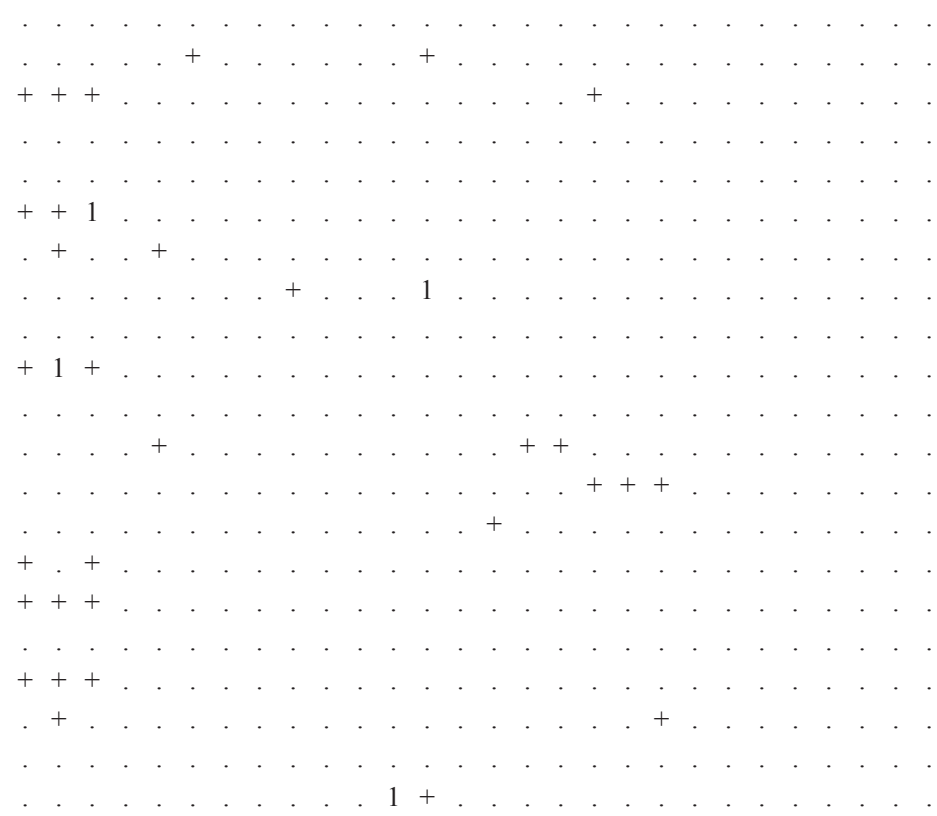

Other species with low frequency: Androsace elongata 6: +; Medicago minima var. brevispina f. pulchella 8: +; Campanula phrygia 11: +; Potentilla inclinata var. incisoserrata f. lanuginosa 15: +; Lathyrus inconspicuus var. inconspicuus 23: +; Parentucelia latifolia 29: +; Thesium macedonicum 54: +; Potentilla suskalovicii 65: +; Euphorbia falcata 70: +; Trigonella gladiata 70: +; Campanula scutellata 1: 1, 2: 1; Picris pauciflora 1: +, 2: +; Trifolium trichopterum 43: +, 44: +; Velezia rigida 1: +, 2: +; Allium sphaerocephalon subsp. sphaerocephalon 19: +, 22: +; Orobanche purpurea 63: +, 65: +; Lactuca viminea subsp. viminea 16: +, 17: +; Camelina rumelica 15: +, 61: +; Sisymbrium orientale var. orientale 57: +, 58: +; Caucalys platycarpos 1: +, 2: +; Bifora radians 13: +; Ranunculus psilostachys 22:+, 23: +; Alyssum stribrnyi var. macedonicum 22: 1, 23: 1; Geranium dissectum 11: +, 14: +; Cynodon dactylon 1: +, 2: +; Alyssum saxatile subsp. orientale 3: +, 56: +; Echium italicum 6: +, 62: +; Orobanche sp. 55: +, 56: +; Papaver dubium 5: +, 65: +; Senecio vulgaris 18: 1, 69: +; Ajuga chamaepitys subsp. chia 64: +, 68: +; Dorycnium herbaceum subsp. macedonicum 63: +. 64: +; Poa angustifolia 65: +, 68: +; Goniolimon tataricum 57: +, 58: +; Scorzonera laciniata 65: +, 68: +; Stipa joannis subsp. joannis 57: +, 59: 1. 
\begin{tabular}{lllllllllllllllllllllllllllllllllllll|lllllllll}
2 & 3 & 3 & 3 & 3 & 3 & 3 & 3 & 3 & 3 & 3 & 4 & 4 & 4 & 4 & 4 & 4 & 4 & 4 & 4 & 4 & 5 & 5 & 5 & 5 & 5 & 5 & 5 & 5 & 5 & 5 & 6 & 6 & 6 & 6 & 6 & 6 & 6 & 6 & 6 & 6 & 7 & 7 & 7
\end{tabular} $\begin{array}{llllllllllllllllllllllllllllllllllllllllllllll}9 & 0 & 1 & 2 & 3 & 4 & 5 & 6 & 7 & 8 & 9 & 0 & 1 & 2 & 3 & 4 & 5 & 6 & 7 & 8 & 9 & 0 & 1 & 2 & 3 & 4 & 5 & 6 & 7 & 8 & 9 & 0 & 1 & 2 & 3 & 4 & 5 & 6 & 7 & 8 & 9 & 0 & 1 & 2\end{array}$

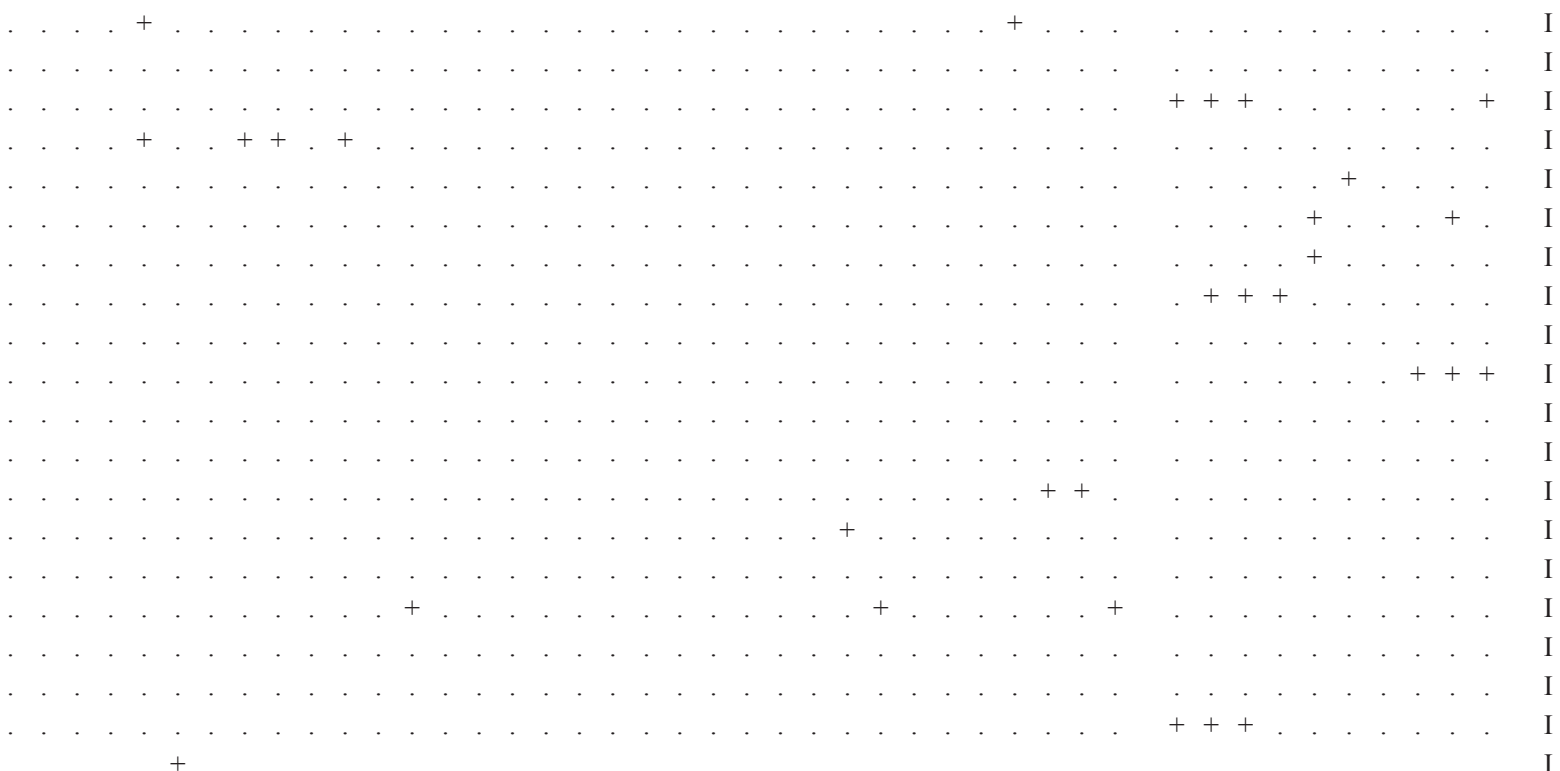

